The following document is a pre-print version of:

Bélanger C, Ross P-S (2018) Origin of nonbedded pyroclastic rocks in the Cathedral Cliff diatreme, Navajo volcanic field, New Mexico. Bull. Volc. 80:article 61, DOI 10.1007/s00445-018-1234-0

\title{
Origin of non-bedded pyroclastic rocks in the Cathedral Cliff diatreme, Navajo volcanic field, New Mexico
}

\author{
Caroline Bélanger*, Pierre-Simon Ross \\ Institut national de la recherche scientifique, 490 rue de la Couronne, Québec (Qc), G1K 9A9, Canada \\ * Corresponding author. \\ E-mail addresses: caroline.belanger.geo@gmail.com (C. Bélanger), rossps@ete.inrs.ca (P.-S. Ross)
}

Keywords:

Diatreme, non-bedded pyroclastic rocks, phreatomagmatic, Navajo volcanic field

\begin{abstract}
Cathedral Cliff is a well exposed mid-Tertiary phreatomagmatic diatreme in the Navajo volcanic field, New Mexico. Post-eruptive erosion, estimated between $500 \mathrm{~m}$ and $1000 \mathrm{~m}$, exposes the deep part of the diatreme. Cathedral Cliff provides an opportunity to examine the transition between the bedded pyroclastic rocks of an upper diatreme, and the non-bedded pyroclastic rocks of the subjacent lower diatreme. Bedded pyroclastic rocks occupy $49 \%$ of the mapped diatreme area, non-bedded pyroclastic rocks occupy $45 \%$, and the remaining $6 \%$ consists of sedimentary megablocks. The bedded pyroclastic rocks range from coarse tuff to medium lapilli tuff, and from lithic to juvenile rich. They were emplaced during eruption at the bottom of the crater by pyroclastic density currents, pyroclastic fallout, and as ballistic bombs and blocks. As the eruption continued, they subsided into the diatreme to their current location. Bedding ranges from well-preserved ("continuous beds") to partially destroyed ("broken beds"). Syn-eruptive subsidence, the passage of debris jets through the broken beds, as well as a concentration of explosions nearby, explains the partial destruction of the bedding. The non-bedded pyroclastic rocks are massive, poorly sorted, and consist of coarse tuff, lapilli tuff and tuff breccia. On average, they are coarser grained and more juvenile rich than the bedded rocks. Non-bedded rocks form zones with steep contacts that cross-cut each other and the bedded rocks. In places, they have gradual transitions into broken beds. We interpret the non-bedded rocks as formed by the passage of debris jets through existing diatreme infill, and from the destruction and recycling of the bedded deposits, with juvenile clast enrichment due to dike fragmentation.
\end{abstract}

\section{Introduction}

Maar-diatremes are the second most abundant type of subaerial volcanoes, after scoria cones (Vespermann and Schmincke 2000), and are locations of hazardous phreatomagmatic eruptions (Lorenz 2007). Their craters cut through the pre-eruptive surface, and are surrounded by thin pyroclastic rings, also called ejecta rings or tephra rings (Lorenz 1986, 2003; White and Ross 2011). A coneshaped diatreme, filled with pyroclastic rocks, underlies the maar (Lorenz 1986; Kurszlaukis and Lorenz 2008; White and Ross 2011). Many maar-diatreme studies have focused on the pyroclastic ring, because this is the typical level of exposure for Quaternary and some Tertiary maars (e.g., Moore et al. 1965; Kienle et al. 1980; Vazquez and Ort 2006). However, these deposits only provide partial information on what happens in the diatreme, since deeper or weaker explosions may not eject material beyond the maar crater (White and Ross 2011; Valentine and White 2012). It is therefore important to also study well-exposed diatremes (e.g., White 1991; Ross and White 2006;
Lefebvre et al. 2013; Delpit et al. 2014) to better understand how maar-diatreme volcanoes work.

Since underground volcanic processes cannot be directly observed, they remain poorly understood. A particularly contentious issue is thus the origin of non-bedded pyroclastic rocks in diatremes, for which a number of explanations have been proposed. These explanations include multiple small volume phreatomagmatic explosions occurring underground along a dike, forming debris jets, and the related mixing and churning of the diatreme infill (White 1991; Kurszlaukis and Lorenz 2008; Valentine and White 2012; Lefebvre et al. 2013). Another proposal is in-vent collapse of a sub-plinian to plinian plume (Porritt et al. 2008; Porritt and Cas 2009). A third group of models involve fluidization processes, either multi-stage "fluidization", whereby the pyroclasts are transported in an eruptive plume inside the diatreme (Gernon et al. 2009), or fluidization of the diatreme by gases passing through the particles at rest (Walters et al. 2006). 
The diversity in proposed origins for the non-bedded pyroclastic rocks in diatremes comes at least partly from the perception that these rocks are massive and homogeneous, with few unambiguous clues about their origin. One way to circumvent this problem is to study the transition between bedded and non-bedded pyroclastic rocks in detail. If the transition is sharp, relatively flat, with a contact that crosses the whole diatreme, then the nonbedded rocks must be older than the bedded ones, and models calling upon rapid emplacement of the non-bedded rocks can be considered (e.g., Walters et al. 2006; Porritt et al. 2008; Gernon et al. 2009). The overlying bedded rocks can then be interpreted separately, and may have formed from a very different eruptive style (e.g., Porritt and Cas 2009; Gernon et al. 2013). However, if the contact between bedded and non-bedded rocks is irregular, sometimes gradational and/or dipping steeply, and if there is evidence that bedded deposits are progressively converted into nonbedded ones (White 1991), then at least some of the nonbedded rocks must be younger than bedded rocks (e.g., Latutrie et al. 2017; this study). In such a scenario, bedded and non-bedded deposits might be forming simultaneously in the diatreme, and the eruptive style responsible for the bedded rocks - about which there may be many clues might also explain the origin of the non-bedded rocks.

Cathedral Cliff is a well exposed mid-Tertiary diatreme located in New Mexico (USA) and is part of the Navajo Nation and Navajo volcanic field (Williams 1936; Semken 2003; Brand et al. 2009; Nybo 2014). The transition between the dominantly bedded upper diatreme and the mostly non-bedded lower diatreme can be explored there, but the Cathedral Cliff outcrops allow genetic relations between the bedded and non-bedded pyroclastic deposits to be examined. This allows an enhanced understanding of the origin of the non-bedded pyroclastic rocks. At Cathedral Cliff, there is evidence that bedded pyroclastic deposits subsided in the diatreme during the eruption and were progressively converted to non-bedded deposits by a range of processes. In this paper, we first present a detailed geological map of Cathedral Cliff showing the distribution of the different lithofacies. These lithofacies are described from field and petrographic observations. We also quantify the componentry with field line counts and petrographic point counts. We then discuss the origin of the bedded and non-bedded facies and present an emplacement model.

\section{Geological setting}

The Navajo volcanic field (NVF), where the Cathedral Cliff diatreme is exposed, lies within the Navajo Nation, and is located in the central part of the Colorado Plateau (Fig. 1a). The Colorado Plateau partially covers four southwestern US states: Arizona, Utah, Colorado and New Mexico. The plateau has been mostly stable for the past $1200 \mathrm{My}$ and occupies an area of $300000 \mathrm{~km}^{2}$ (McGetchin et al. 1977). Using the K-Ar method, an age range of 33.9 Ma to 19.4 Ma was obtained for the NVF (Roden et al. 1979; Laughlin et al. 1986). Recent studies by Nybo et al. (2011) and Nybo (2014) using the Ar-Ar method on phlogopite and sanidine reveal a much tighter age distribution, between 26.2 Ma and 24.7 Ma.

The NVF comprises more than 80 volcanoes and intrusions of Oligocene to Miocene age, mostly of minette composition (Fig. 1b; Williams 1936; McGetchin et al. 1977; Roden 1981; Semken 2003). Minette is a potassic mica lamprophyre which cannot be chemically distinguished from normal igneous rocks (Le Maître 2002). Minettes from the NVF are generally composed of an aphanitic matrix formed of alkali feldspar, diopside, phlogopite and apatite, and of phenocrysts of phlogopite, diopside and sometimes olivine (Roden 1981; Semken 2003). A small portion of the volcanoes consist of "serpentinized ultramafic microbreccias" of unclear origin (Semken 2003). Most of the volcanoes in the NVF are maar-diatremes, with deep enough erosion to expose the lower diatreme (Williams 1936; Delaney 1987). The diatremes are composed mainly of juvenile-rich lapilli tuffs and tuff breccias (Williams 1936). Since the erosion level is not uniform throughout the volcanic field, some shallower structures are also preserved, e.g., the Narbona Pass maar, as well as lava flows at Sonsela Butte and The Palisades (Appledorn and Wright 1957; Semken 2003; Brand et al. 2009).

This study focuses on Cathedral Cliff, a diatreme located in the NW part of New Mexico (Fig. 1b). In this region, the amount of post-eruptive erosion is estimated as $500 \mathrm{~m}$ to $1000 \mathrm{~m}$ (Delaney and Pollard 1981). The sedimentary host rocks are probably $1 \mathrm{~km}$ thick above the Precambrian crystalline basement (Delaney 1987). At the current level of erosion, the Mancos Shale is the sedimentary formation exposed (Delaney 1987). A N-S-oriented minette dike 200 $\mathrm{m}$ south of Cathedral Cliff has a visible strike length of 590 m (Fig. 1c).

\section{Methods}

For this study, detailed topographic and geological maps of the Cathedral Cliff diatreme were made using a Lasertech TruPulse 200X laser range finder coupled with a Lasertech MapStar TruAngle angle encoder (Fig. 2). We measured the position of geological contacts and other features of interest, such as bedding planes, from a base station and ten secondary stations (Fig. 2, inset map). The topographic contours and geological contacts are based on 1495 and 626 surveying points, respectively. In addition, the geology of the sub-vertical South and East walls of the massif were drawn over photographs to define steep contacts more precisely (Fig. 3).

A detailed lithological description for each pyroclastic facies was made in the field which included definition of the size, shape, abundance and aspect of the different types of fragments. The pyroclastic rocks were described using the terminology of White and Houghton (2006). Twentyfour line counts - eleven in the bedded pyroclastic rocks, and thirteen in the non-bedded pyroclastic rocks - were used to quantify the proportions of the matrix, and the 
componentry of fragments larger than or equal to $4 \mathrm{~mm}$ in the different facies. Line counts were done by measuring the length of these fragments ( $\geq 4 \mathrm{~mm}$ ), along a line of $1 \mathrm{~m}$ (see Lefebvre et al. 2013).

Seventeen samples were collected in the different facies of the Cathedral Cliff diatreme (juvenile bombs and pyroclastic rocks), in addition to one sample from the minette dike to the South and two samples (juvenile bombs) from the nearby Barber Peak diatreme, about $2 \mathrm{~km} \mathrm{SE}$ of Cathedral Cliff. The samples of the juvenile bombs and the minette dike were used for geochemistry (see Supplementary material, which shows that the new analyses are similar to other minettes from the Navajo volcanic field). Twenty-nine thin sections were made from these samples to study the smaller lithic and juvenile fragments $(<4 \mathrm{~mm})$ and cement of the pyroclastic rocks. They also allowed the study of the mineralogy and textures of the lithic and juvenile fragments as well as the coherent samples (see Supplementary material). The componentry of the $<4 \mathrm{~mm}$ clasts in pyroclastic rocks was point counted on the thin sections using a target of 400 points per sample.

\section{Geological overview of Cathedral Cliff}

At the present level of erosion, the Cathedral Cliff diatreme is about $250 \mathrm{~m}$ across and the massif reaches a height of approximately $125 \mathrm{~m}$ above the surrounding plain (Fig. 2, inset). On the topographic map (Fig. 2, inset), the pyroclastic rocks from the blue area are well exposed, and accessible, and so were mapped in detail. The outer portion of the diatreme is not well exposed ("non-differentiated diatreme" on the map). The central-top portion of the diatreme also could not be mapped in detail due to difficult access, but some general observations were made. Geological contacts on the southern and eastern subvertical walls of the diatreme were also mapped on sideview photos (Fig. 3).

In summary, at the current level of exposure, Cathedral Cliff consists entirely of bedded and non-bedded diatremefilling pyroclastic rocks (Table 1), with some sedimentary megablocks. At this level there are no coherent dikes or post-eruptive crater infill. Within the area mapped in detail, $49 \%$ of the outcrop consists of bedded pyroclastic rocks, separated into continuous beds and broken beds. Then $45 \%$ of the outcrop consists of non-bedded pyroclastic rocks. Finally, sedimentary megablocks comprise the remaining $6 \%$, and tuff dykes account for much less than $1 \%$. These proportions are in terms of surfaces measured in map view (Fig. 2).

At Cathedral Cliff, three different types of contacts can be found. These are, first, sharp steep to sub-vertical contacts between bedded pyroclastic rocks and non-bedded pyroclastic rocks (Fig. 4a), commonly defining columns of non-bedded pyroclastic rocks (Fig. 4b). Second, we find sharp sub-vertical contacts between different domains of non-bedded pyroclastic rocks (Fig. 4c). Finally, we observed gradual contacts between broken beds and nonbedded pyroclastic rocks (not shown).

\section{Facies descriptions}

At Cathedral Cliff, there are two main bedded pyroclastic facies: (1) continuous beds and (2) broken beds (Fig. 2; Table 1). The continuous beds are found on the south and SE part of the diatreme, and the broken beds are exposed on the $\mathrm{W}$ side. Small domains of bedded pyroclastic rocks also remain in the non-bedded facies, on the SW side - as shown by the red line in the NBjf zone of Fig. 2 - and on the east side of the diatreme.

Bedded pyroclastic rocks I: continuous beds

The continuous beds $(C B)$ form a well-preserved inwarddipping package where individual beds can be followed laterally over several meters $(2-23 \mathrm{~m})$, as shown by the red lines on the geological map (Fig. 2). The beds collectively form a $115^{\circ}$ arc and measured dips range from $71^{\circ}$ to $89^{\circ}$ towards the center of the diatreme in the area mapped in detail, with most between $70^{\circ}$ and $80^{\circ}$. At the top of the massif, beds dip inward, but with gentle to moderate $\left(20^{\circ}\right.$ to $55^{\circ}$ ) dips. This probably means that there is an unconformity in the bedded pyroclastic rocks at middle heights in the massif. However, given the intense weathering of much of the steepest part of the south face, we cannot rule out a progressive upward transition from steep to moderate dips. All the same, the stratigraphic polarity faces the center of the diatreme. The beds are generally $\mathrm{mm}$ to $\mathrm{cm}$ thick, with rare lapilli tuff beds up to $38 \mathrm{~cm}$ thick. Bedding is mostly plane parallel (Fig. 5a), but some rare dunes, bomb sags, and cross-bedding are present (Fig. 5b-c).

Two sub-facies can be defined in the continuous beds (Table 1, Fig. 2). The first $10.7 \mathrm{~m}$ (true thickness) of the bedded sequence consists of quartz-rich tuffs and lapilli tuffs $(\mathrm{CBl})$. The rest of the sequence $(20.7 \mathrm{~m}$ thick where measured) is composed of juvenile-rich coarse tuffs and fine to medium lapilli tuffs, with 5\% to $60 \%$ lapilli (CBj). In these two sub-facies, the sparse lithic lapilli are subangular to round and are mainly composed of white, reddish or greenish siltstones. The juvenile lapilli are round to sub-angular, rarely amoeboid or irregular in shape. The tuffaceous matrix of the rocks consists of rounded to subangular sedimentary quartz grains, and sub-rounded to angular juvenile fragments (Fig. 5d-e).

Bedded pyroclastic rocks II: broken beds

The bedding in the broken beds $(B B)$ facies is difficult to follow laterally for more than a few meters (Figs. 6a, 6b). The broken beds also commonly display a progressive disaggregation of the bedding (Fig. 6c). In places, the bedding seems totally destroyed, which creates local domains of non-bedded pyroclastic rocks (Fig. 6b, below yellow dashed line). Those unbedded domains are composed of fine to medium lapilli tuff, and are several meters to tens of meters in size. The dips of the beds face $S$ and SE, and vary from $30^{\circ}$ to $55^{\circ}$ (Fig. 2), but reach $70^{\circ}$ 
locally. The brownish pyroclastic rocks from the broken beds are composed of coarse tuff and fine to medium lapilli tuff, with $15 \%$ to $55 \%$ lapilli. This is very similar to the juvenile-rich continuous beds $(\mathrm{CBj})$ sub-facies. The beds are also millimetric to centimetric in thickness, and show local bomb sags (Fig. 6d). Similar to the continuous beds, the tuffaceous matrix is composed of rounded to subangular quartz grains, and sub-rounded to angular juvenile fragments (Fig. 6e).

Non-bedded pyroclastic rocks

The non-bedded pyroclastic rocks are mostly found on the NE and SW sides of the diatreme (Fig. 2). To the NE, they form mutually cross-cutting subvertical zones (Fig. 4c). Non-bedded pyroclastic rocks also cross-cut the continuous beds and the broken beds, forming sub-vertical columns (Fig. 4b). These rocks are poorly sorted and massive. The majority of non-bedded pyroclastic rocks are rich in juvenile fragments $(\mathrm{NBj})$. In the $\mathrm{SW}$ portion of the diatreme there are two lithic-rich facies: a lithic breccia (LB) and a fine quartz-rich lapilli tuff (NBlf) (Fig. 2).

The lithic breccia $(L B)$ comprises blocks and megablocks of gray quartzofeldspatic sandstones, which can reach $20 \mathrm{~m}$ across, with decimetric to metric domains of non-bedded lapilli tuff in between (Fig. 7a). This quartz-rich lapilli tuff comprises $10 \%$ sub-angular to round juvenile lapilli.

A fine quartz-rich lapilli tuff (NBlf) can be found NE of the LB (Figs. 2, 7b). The proportion of lapilli in this facies ranges from $20 \%$ to $40 \%$, with at least half being juvenile. The lithic lapilli are round to sub-angular and composed of greenish, reddish and white siltstones and shales. The ash size fraction is dominated by quartz grains which are derived from the sedimentary country rock.

The juvenile-rich non-bedded pyroclastic rocks (NBj) are mainly lapilli tuffs, with the particle size of the lapilli and the proportion of blocks defining the different sub-facies. Fine lapilli tuffs (NBjf) are composed of $30 \%$ to $55 \%$ lapilli and they are mostly located on the $\mathrm{S}$ and $\mathrm{E}$ sides of the diatreme (Figs. 2, 7c). Medium lapilli tuffs (NBjm) contain $40 \%$ to $60 \%$ lapilli and are found on the $\mathrm{W}$ and $\mathrm{N}$ portion of the diatreme (Figs. 2, 7d). The coarse lapilli tuffs (NBjc) are composed of $45 \%$ to $80 \%$ lapilli and are present in the NE part of the diatreme (Figs. 2, 7e). In all those sub-facies, the black, brownish and greenish juvenile fragments are rounded to sub-angular, but some of them are amoeboid in shape. Lithic fragments are of the same types as in the bedded facies.

In the juvenile-rich fine lapilli tuff ( $\mathrm{NBjf}$ ) on the $\mathrm{S}$ side of the diatreme, $10 \%$ to $20 \%$ fragments of bedded pyroclastic rocks remain near the contact of the $\mathrm{NBjf}$ with the continuous beds (Fig. 7f). A 5-m-long bedded fragment can also be found in the juvenile-rich coarse lapilli tuff ( $\mathrm{NBjc})$ located on the $\mathrm{E}$ wall of the diatreme (the orange fragment in the NBjc on Fig. 2). As with the bedded facies, the tuffaceous matrix of the pyroclastic rocks of the non- bedded facies consists of rounded to sub-angular sedimentary quartz grains, and juvenile fragments, subrounded to angular in shape (Fig. $7 \mathrm{~g}$ ).

Tuff dikes

Two main tuff dikes were mapped (Figs. 2, 3a). That of the south wall is $9 \mathrm{~cm}$ thick and is composed of coarse tuff with $0 \%$ to $20 \%$ lapilli. Locally, lapilli are concentrated in the middle of the dike. The dike is mostly oriented $210^{\circ} \mathrm{N}$, dipping $15^{\circ}$. The second dike is found on the east wall of Cathedral Cliff, and is up to $1 \mathrm{~m}$ thick. It is composed mainly of coarse tuff and fine lapilli tuff with $0 \%$ to $25 \%$ lapilli.

\section{Types of fragments}

Juvenile material

We distinguish two types of juvenile fragments at Cathedral Cliff based on field observations and petrography. In the field, the type 1 juvenile fragments are dark gray to black with an angular to sub-round shape (Fig. 8a). Their size can vary from $0.3 \mathrm{~mm}$ (observable in thin section) to a few $\mathrm{dm}$. They are generally non-vesicular and microcrystalline or tachylitic (Fig. 8b). Their mineralogy and textures are very similar to the minette dike located south of Cathedral Cliff (see Supplementary material for the dike description).

Type 2 juvenile fragments are characterized by a brownish to greenish color in the field and a round to sub-angular shape (Fig. 8c). In detail, the larger fragments can have an amoeboid or a globular shape, while smaller ones are round to sub-angular. These fragments typically have a vesicle content of between $0 \%$ and $1 \%$ vesicles, but some have up to $30 \%$. Type 2 juvenile fragments are strongly altered to palagonite, clay and sometimes carbonates, which explains their color (Fig. 8d). This alteration probably affects former volcanic glass (sideromelane). In general, the size of the type 2 fragments varies from $0.25 \mathrm{~mm}$ to more than $10 \mathrm{~cm}$.

Both types of juvenile fragments contain relatively fresh phlogopite phenocrysts, usually smaller than $300 \mu \mathrm{m}$, along with diopside, feldspar, and more rarely olivine, all commonly smaller than $500 \mu \mathrm{m}$. These minerals, especially phlogopite, can sometimes be found as free crystals in the ash fraction of the pyroclastic rocks. Quartz grains of sedimentary origin are occasionally incorporated in the border of some juvenile fragments, but they can also be found inside the fragments. The crystalline groundmass of type 1 juvenile fragments versus the altered glassy groundmass of the type 2 juvenile fragments suggest a different cooling rate for the two types of fragments. We interpret type 2 fragments as having been derived from fragmentation and rapid cooling of the hot active dike in the diatreme or root zone, in the presence of external water. Type 1 fragments might be derived from dikes that have cooled more slowly, perhaps because they were emplaced in drier portions of the diatreme and then fragmented by later explosions. 
Lithic material

Lithic material in the pyroclastic rocks is dominated by rounded to sub-angular quartz grains, mainly monocrystalline and derived from the sedimentary country rocks. On average, the size of the quartz grains varies between 0.05 to $0.25 \mathrm{~mm}$. Small free plagioclase and microcline grains can also be found in the ash fraction.

Fragments of the country rocks are less abundant than free quartz grains. They are mainly composed of green, white, gray and reddish siltstones and fine sandstones (Fig. 8e-f). They are rounded to sub-angular in shape and mostly of fine lapilli and coarse ash in size. Sedimentary blocks and megablocks can also be found.

\section{Componentry}

The 24 line counts completed in the field were used here to define the proportion of matrix (defined as $<4 \mathrm{~mm}$ for the line counts only), and the proportion of juvenile and lithic fragments that are larger or equal to $4 \mathrm{~mm}$. The results show that the apparent proportion of the matrix is significant for each facies and varies from $72.7 \%$ to $98.5 \%$. However, the apparent proportion of matrix is slightly higher, on average, for the continuous beds $(90.8 \%)$ than for the non-bedded facies $(86.5 \%)$ (Fig. 9a).

Among the $\geq 4 \mathrm{~mm}$ fragments, when all facies are considered, type 2 juvenile fragments are the most abundant (26\% to $100 \%$, with an average of $74 \%$ ) (Fig. 9b). In comparison type 1 juvenile clasts have a range of $0 \%$ to $63 \%$, with an average of $26 \%$. Finally, lithic fragments range between $0 \%$ to $18 \%$, with an average of $5 \%$ (Fig. $9 \mathrm{~b}$ ). In the $\geq 4 \mathrm{~mm}$ fraction, there is no major difference between the average amount of lithic versus juvenile fragments for the continuous beds (6\% and $94 \%$ respectively) and the non-bedded facies (5\% and 95\% respectively) (Fig. 9b).

The 18 petrographic point counts give the componentry of the $<4 \mathrm{~mm}$ fraction and the cement. They show that, on average, the non-bedded facies contain more juvenile elements in comparison with the continuous beds facies (Table 2). The point-counted continuous beds contain a mean value of $39 \%$ juvenile clasts and $43 \%$ lithic clasts. The non-bedded pyroclastic rocks possess mean proportions of $53 \%$ juvenile clasts and $34 \%$ lithic clasts. In detail, some continuous beds samples, numbered 3A, 27 and 28 , possess a juvenile composition similar to the nonbedded facies. There are also non-bedded samples, number 9 and 15, that have a lithic composition similar to the continuous beds facies. The proportion of unresolvable material and cement are generally comparable for the continuous beds and the non-bedded facies.

\section{Interpretation: origin of the main lithofacies groups}

We interpret the Cathedral Cliff diatreme as the result of explosive underground interaction of magma with groundwater or water-saturated sediments, in line with the previous literature on maar-diatreme volcanoes (Lorenz 1986; Sohn and Cough 1989; Kurszlaukis and Lorenz
2008; White and Ross 2011; Valentine and White 2012; Lefebvre et al. 2013). We discuss the origin of the main lithofacies groups within this framework.

\section{Continuous beds}

The continuous beds cover nearly half of the mapped area. Given that the beds dip steeply toward the center of the diatreme, and that $500 \mathrm{~m}$ to $1000 \mathrm{~m}$ of post-eruption erosion is inferred (Delaney and Pollard 1981), it is unlikely that the continuous beds were deposited where they are presently found. Instead, they were deposited at the bottom of the syn-eruptive crater, and then subsided through the eruption to their present location. We come back to the issue of subsidence below, but first discuss depositional processes.

\section{Mode of deposition}

The continuous beds, composed of coarse tuffs and fine lapilli tuffs, are characterized by hundreds of thin beds ( $\mathrm{mm}$ to $\mathrm{dm}$ thick). The bedding is mostly plane parallel but dunes and cross-bedding are found locally. These characteristics are compatible with pyroclastic density currents and proximal fallout deposition (Sohn and Chough 1989; White 1991; Vazquez and Ort 2006; White and Ross 2011). To form dunes and plane-parallel beds from pyroclastic density currents, a certain amount of lateral transport is necessary to obtain the suitable flow conditions (Sohn and Chough 1989). This suggests deposition of the continuous beds in a rather large crater. Occasional bomb sags indicate that ballistic bombs fell into damp fine-grained pyroclastic deposits that could deform plastically (Fisher and Schmincke 1984; Vazquez and Ort 2006).

The presence of hundreds of beds shows the pulsating character of the explosive volcanic activity at Cathedral Cliff. The continuous beds were produced by a multitude of small-volume explosions, which is typical of phreatomagmatic eruptions responsible for the formation of maar-diatremes (Lorenz 1986; Valentine et al. 2014).

\section{Compositional variation}

The pyroclastic deposits formed during the initial stage of the eruption will typically be richer in lithic fragments than the pyroclastic deposits that follow in the pyroclastic ring (e.g. Kienle et al. 1980; White 1991; White and Ross 2011) or at the bottom of the syn-eruptive crater. This is because the sedimentary host rocks are excavated during the early stages of cratering and formation of the proto-diatreme. With time and continued delivery of magma, the diatreme will become progressively enriched in juvenile material (Lefebvre et al. 2013), and so too will debris ejected from it. This explains why the lithic-rich beds at the base of the sequence at Cathedral Cliff (CBl facies) evolve into a more juvenile-rich composition towards the stratigraphic top (CBj facies).

\section{Subsidence}

The continuous beds were initially deposited subhorizontally or with shallow dips on the floor of the crater 
by dilute pyroclastic density currents and fallout. They now dip steeply towards the centre of the diatreme. They are inferred to have reached their present depth by subsiding in the diatreme, most strongly near its center, during the eruption and perhaps afterwards.

The available figure for the vertical distance between the pre-eruptive surface and the current plain is $500-1000 \mathrm{~m}$ at Ship Rock, located $15 \mathrm{~km}$ NW of Cathedral Cliff (Delaney and Pollard 1981). However, the $500 \mathrm{~m}$-tall Ship Rock massif does not seem to expose any lacustrine sediments or other post-eruptive crater infill deposits at its top. This indicates that a part of the Ship Rock diatreme has been eroded, and that the bottom of the crater was more than $500 \mathrm{~m}$ above the surrounding plain at this location. We therefore use a range of $600-1000 \mathrm{~m}$ for the distance between the pre-eruptive surface and the current plain above which Cathedral Cliff rises. We assume a flat topography and flat sedimentary strata between Ship Rock and Cathedral Cliff.

From the distance between the pre-eruptive surface and the current plain, we subtract the likely depth of the final syneruptive crater, $200 \mathrm{~m}$ to at most $300 \mathrm{~m}$ based on the literature (Ross et al. 2011). This yields a range of 300 to $800 \mathrm{~m}$ for total subsidence. We believe that this was partitioned into syn-eruptive and post-eruptive subsidence (Suhr et al. 2006; Lorenz 2007), but we cannot quantify the role of each. For comparison, in the Missouri River Breaks volcanic field, which is an extreme case, the diatremes have been affected by $1.0 \mathrm{~km}$ to $1.3 \mathrm{~km}$ of total subsidence, including syn-eruptive subsidence estimated between 800 $\mathrm{m}$ to $1.1 \mathrm{~km}$ (Delpit et al. 2014).

\section{Broken beds}

The broken beds are very similar to the continuous beds, more specifically the juvenile-rich continuous beds facies $(\mathrm{CBj})$, in terms of structure, texture and composition. The broken beds display local bomb sags, have millimetric to decimetric planar beds, and have a juvenile-rich composition, similar to the $\mathrm{CBj}$ facies. We therefore infer that the broken beds share a similar origin with the continuous beds. However, the major difference is the state of preservation of the primary structures. The bedding in the broken beds facies is difficult to follow for more than a few meters, and is in places totally destroyed, which creates local domains of non-bedded pyroclastic rocks. The partial destruction of the bedding and the formation of local domains of non-bedded pyroclastic rocks can be explained by the passage of debris jets (Ross and White 2006) through the broken beds, and/or by syn-eruptive subsidence, and/or by a concentration of explosions under or near the broken beds area. When the bedding is totally destroyed, nonbedded pyroclastic rocks are created. Thus, the broken beds are considered to be a transitional facies between continuous beds and non-bedded pyroclastic rocks.
Non-bedded pyroclastic rocks

We examine three main, but non-mutually exclusive, origins for the non-bedded pyroclastic rocks. These are (1) debris jets and related stirring, (2) subsidence of pyroclastic material into the diatreme, (3) recycling of bedded pyroclastic material. We also briefly consider other hypotheses.

\section{Debris jets and related stirring}

Columns of non-bedded pyroclastic rocks are interpreted to reflect the passage of debris jets through the diatreme during the eruption. These debris jets, characteristic of lower diatremes (White and Ross 2011), are thought to be composed of pyroclastic material, steam, magmatic gas and sometimes liquid water, and are the result of phreatomagmatic explosions in the diatreme, mobilizing pyroclastic material toward the surface (McClintock and White 2006; Ross and White 2006). Some debris jets can reach the surface, and feed the eruptive plume, whereas others remain totally subterranean. The multiple small volume phreatomagmatic explosions, besides forming the debris jets, will favor the gradual stirring of the pyroclastic deposits present near those explosion sites. The stirring will destroy existing bedding (White 1991; Lefebvre et al. 2013).

\section{Subsidence}

Bedding will become more difficult to preserve during syneruptive subsidence with the narrowing of the diatreme at depth. Depth-controlled subsidence deformation cannot, however, have been the only mechanism responsible for the destruction of the bedding at Cathedral Cliff, because the continuous beds and the broken beds are found at the same elevation. Other processes, such as the passage of debris jets, and the accompanying stirring of the deposits, must have also occurred in the diatreme where the bedding is totally destroyed or non-existent.

\section{Recycling of bedded pyroclastic deposits}

Debris jets and stirring of the existing pyroclastic deposits will gradually destroy the bedding, and because new magma is involved in each explosion, there will be a progressive change in the grain size and the composition of the pyroclastic material in the diatreme. In the NBjf facies, found in the southern portion of the diatreme, approximately $10 \%$ to $20 \%$ of the deposit consists of domains of bedded pyroclastic rocks. Their presence strongly suggests that continuous beds were initially present there, and have been destroyed because of their proximity to multiple explosions sites and with the passage of debris jets through them.

Based on componentry data, in order to reach the average non-bedded composition, the continuous beds need to be enriched with juvenile material. Simple models are presented here to illustrate the number of juvenile addition cycles required to transform the continuous beds within the diatreme to a composition similar to that of the non-bedded rocks (Fig. 10). For each cycle of magma fragmentation 
within the diatreme, we add juvenile clasts to the existing diatreme-filling deposits but no additional country rock.

The first model uses a constant $20 \%$ juvenile addition rate per explosion, but considers the effect of different starting compositions (Fig. 10a). Consider the blue curve of Fig. $10 \mathrm{a}$ which begins at $48 \%$ juvenile material, i.e. the average composition of the continuous beds. On average, the continuous beds are composed of $39.2 \%$ material juvenile and $42.7 \%$ lithic material (Table 2), but excluding the very fine ash and the cement, and bringing back the total to $100 \%$, we obtain $47.9 \%$ juvenile material, and $52.1 \%$ lithic material. Suppose that the volume affected by one explosion contains 100 'units' of existing diatreme infill, of which 48 units are juvenile and 52 are lithic (Fig. 10b, top). After a first explosion cycle, we now have 68 juvenile units but the total is 120 units. The proportion of juvenile material is therefore $[(48+20) /(100+20)] \times 100=57 \%$ in the zone affected by the explosion (Fig. 10b, second cartoon). For simplicity, we suppose that addition of juvenile pyroclasts from below is balanced by permanent ejection of material from the maar crater (Fig. 10b, third cartoon). This brings back the total number of units to 100 , of which 57 are juvenile and 43 are lithic (Fig. 10b, bottom). The proportion of juvenile material at the end of the second cycle is then $[(57+20) /(100+20)] \times 100=64 \%$. After the third cycle, the proportion of juvenile material is $70 \%$ and after the fourth one, 75\% (Fig. 10a, blue curve). The average proportion of juvenile material in the non-bedded pyroclastic rocks is $61 \%$ (this again excludes the very fine ash and the cement). As a result, two juvenile addition cycles are necessary to convert the average continuous beds composition to the average non-bedded composition. Other curves show the effect of different starting compositions (Fig. 10a).

The second model (Fig. 10c) considers only the average composition of the continuous beds as a starting material, but varies the addition rate of new juvenile material added from each new explosion from 10 to $40 \%$. If the addition rate is as low as $10 \%$, it takes four cycles to reach the average composition of non-bedded pyroclastic deposits. At $40 \%$ addition, it takes only one cycle. Of course Nature is much more complex than these simplified scenarios used for illustrative purposes. The juvenile enrichment is not necessarily continuous, and there may be a contribution of new lithic material through diatreme enlargement. However the long-term trend is towards juvenile enrichment.

\section{Other hypotheses}

Other hypotheses have been suggested to explain the formation of non-bedded pyroclastic rocks in diatremes, especially for kimberlitic cases. For example, Porritt et al. (2008) propose that the formation of non-bedded volcaniclastic kimberlite is from the in-vent collapse of a plinian to sub-plinian eruption plume coupled with magmatic fragmentation. Gernon et al. (2009) propose a multi-step "fluidization" model, by which they mean transport of the pyroclasts in an eruptive plume within the diatreme, and not fluidization in the industrial sense of the term. Walters et al. (2006) also invoke fluidization of the diatreme but use the term in a sense more consistent with the industrial process (Reynolds 1954), where gases pass through a bed of particles originally at rest.

These other hypothesized processes are not considered to have formed the non-bedded pyroclastic rocks of Cathedral Cliff. As addressed previously, we infer that the Cathedral Cliff pyroclastic rocks have a phreatomagmatic origin. Evidence presented that the continuous beds and crosscutting non-bedded columns were formed by multiple small explosions is inconsistent with emplacement during a single sustained plinian to sub-plinian eruptive phase. The fluidization models involve an eruption dominated by a constant discharge of material, or an extreme amount of gas exiting a small dike at the very end of the eruption to fluidize the entire diatreme.

\section{Evolution of the diatreme}

We propose a five-stage conceptual model for the evolution of Cathedral Cliff, illustrated by a section oriented SW-NE, located approximately along A-A' on Fig. 2. First, the minette dike ascends towards the paleo-surface (Fig. 11a). Then the dike interacts explosively with underground water or water-saturated sediments (Valentine and White 2012). The most effective conditions for explosive excavation are present near the surface, forming the proto-maar and protodiatreme (Fig. 11b; Valentine and White 2012). The pyroclastic material initially produced is mainly composed of the country rock excavated during the formation of the early crater, with few juvenile fragments (White 1991). It is not clear if bedding, including pyroclastic dunes, can form at this stage at the bottom of the small crater, but the $\mathrm{CBl}$ facies might have been formed then, or later.

With widening and deepening of the crater, the walls become unstable and collapse locally, as observed at Ukinrek (Kienle et al. 1980; Lorenz and Kurszlaukis 2007). This explains the local country-rock breccias (LB facies, Fig. 11c; Lefebvre et al. 2015). A part of the pyroclastic ring could also collapse into the crater simultaneously, which would explain the pyroclastic matrix between the sandstone megablocks in the LB facies. Alternatively, this matrix could come from the active eruptive burst at the time of the collapse of the walls.

In addition to repeated explosions enlarging the crater, occasional deeper explosions/fragmentation sites will result in the formation of a diatreme with steep walls (Figs. 10c-d, Kurszlaukis and Lorenz 2008). Phreatomagmatic explosions in the diatreme create debris jets, some of which feed the eruptive plume, while others do not necessarily reach the surface (McClintock and White 2006; Ross and White 2006; Valentine and White 2012). The formation of debris jets in the diatreme will mobilize pyroclastic material upward and create space at depth into which the bedded pyroclastic deposits can subside (Fig. 11d; Lorenz 
1975; Delpit et al. 2014). At depth, it is difficult to maintain the bedding because the diatreme becomes narrower (Lorenz 1986; White and Ross 2011), and explosions as well as debris jets in this region repeatedly displace and deform the bedded deposits (White 1991; Delpit et al. 2014). This progressively creates the lower (non-bedded) diatreme. Meanwhile, most of the bedded upper diatreme ( $\mathrm{CBj}$ facies and eventually $\mathrm{BB}$ facies) develops by continued deposition at the bottom of the crater, with modification by syn-eruptive subsidence (Figs. 11c-d).

At Cathedral Cliff, the explosion focus eventually migrated to the NE, where there is a significant concentration of nonbedded pyroclastic rocks (Fig. 11e). This migration caused an unconformity in the bedded pyroclastic rocks, explaining the weak to moderate dips observed at the top of the massif. An alternative interpretation is that the inferred unconformity is related to a change in the vertical position of the crater associated with a more intense eruptive phase emptying a portion of the upper diatreme (not shown in Fig. 11). After the end of the eruption, over a period of about 25 My, erosion inverted the topography and exposed the transition between the upper bedded diatreme and the lower non-bedded diatreme, at least 500-600 m below the preeruptive surface (Fig. 11e, dashed line).

\section{Conclusions}

Cathedral Cliff is a well exposed, deeply eroded, midTertiary phreatomagmatic volcano, which allows the transition from bedded pyroclastic rocks ("upper diatreme") to non-bedded pyroclastic rocks ("lower diatreme") to be mapped. Having both types of pyroclastic rocks exposed in the same diatreme allows relations between them to be studied, and progress to be made in our understanding of the origin of non-bedded pyroclastic rocks.

At Cathedral Cliff, the transition between the upper and lower diatreme does not take place at a single level. Bedded and non-bedded facies coexist in sub-equal proportions over the full height of the massif $(\sim 125 \mathrm{~m})$. Sharp subvertical contacts between bedded pyroclastic rocks and cross-cutting columns of non-bedded pyroclastic rocks indicate that some of the non-bedded rocks are younger than some of the bedded ones. Gradational contacts between broken beds and non-bedded pyroclastic rocks suggest a progressive transformation of bedded rocks into non-bedded rocks. Therefore, the non-bedded rocks cannot have been emplaced quickly at an early stage with a high eruption rate, with the bedded pyroclastic rocks then deposited on top with a different eruption style and rate. Instead, the two facies groups formed together, progressively, during the evolution of the diatreme, and clues about eruptive style from the bedded rocks can be used to inform the origin of the non-bedded rocks.

The bedded pyroclastic rocks are about $500 \mathrm{~m}$ to $1000 \mathrm{~m}$ below the pre-eruptive surface, at the current level of erosion. The beds were deposited in the syn-eruptive crater by dilute pyroclastic currents, pyroclastic fallout, and ballistic bombs, as a consequence of phreatomagmatic explosions in the diatreme. The beds then subsided into the diatreme to their current location. Bedding ranges from well-preserved ("continuous beds") to partly destroyed ("broken beds"). The partially destroyed bedding and local non-bedded domains in the broken beds resulted from the passage of debris jets, syn-eruptive subsidence and disaggregation, and by a concentration of explosions near or under the broken beds.

The non-bedded pyroclastic rocks are another major facies in the diatreme. They were deposited from debris jets passing through existing bedded and non-bedded pyroclastic rocks, and also formed by destruction and recycling of bedded deposits in the diatreme infill. This destruction was caused both by debris jets and by syneruptive subsidence. The high juvenile clast content of some non-bedded rocks indicate enrichment by multiple episodes of magma fragmentation and debris jet emplacement. Over time, some of the bedded pyroclastic rocks that had subsided within the diatreme during the eruption were gradually converted into non-bedded deposits.

\section{Acknowledgements}

We would like to thank J. Stix and M. Malo for reviewing and evaluating the MSc thesis of the first author, from which this paper is derived. We also thank F. Bédard and É. Döhring for their great help in the field. J.D.L. White visited Cathedral Cliff with PSR and is acknowledged for a useful pre-submission review of the manuscript. Field work on the Navajo Nation was conducted under a permit from the Navajo Nation Minerals Department. Any persons wishing to conduct geological investigations on the Navajo Nation must first apply for, and receive, a permit from the Navajo Nation Minerals Department, P.O. Box 1910, Window Rock, Arizona 86515, USA, telephone: 1-928871-6587. We thank two anonymous reviewers for constructive journal reviews as well as associate editor Jacopo Taddeucci and executive editor Andrew Harris for efficient handling of the manuscript.

\section{References}

Appeldorn CR, Wright HE (1957) Volcanic structures in the Chuska Mountains, Navajo Reservation, Arizona-New Mexico. Geol Soc Am Bull 68:445-468.

Brand BD, Clarke AB, Semken S (2009) Eruptive conditions and depositional processes of Narbona Pass Maar volcano, Navajo volcanic field, Navajo Nation, New Mexico (USA). Bull Volcanol 71:49-77.

Cashman KV, Sturtevant B, Papale P, Navon O (2000) Magmatic fragmentation. in: Encyclopedia of Volcanoes, p. 421-430.

Crowe BM, Fisher RV (1973) Sedimentary structures in basesurge deposits with special reference to cross-bedding, Ubehebe Craters, Death Valley, California. Geol Soc Am Bull 84:663-682. 
Delaney PT (1987) Ship Rock, New Mexico: the vent of a violent volcanic eruption. GSA, Centennial Field Guide - Rocky Mountain Section, p. 411-415.

Delaney PT, Pollard DD (1981) Deformation of host rocks and flow of magma during growth of minette dikes and brecciabearing intrusions near Ship Rock, New Mexico. U.S. Geol Surv Prof Paper 1202, 61 p.

Delpit S, Ross P-S, Hearn BC (2014) Deep-bedded ultramafic diatremes in the Missouri River Breaks volcanic field, Montana, USA: $1 \mathrm{~km}$ of syn-eruptive subsidence. Bull Volcanol 76:1-22

Fisher RV, Schmincke H-U (1984) Pyroclastic Rocks. SpringerVerlag, Berlin, 472 p.

Fisher RV, Waters AC (1970) Base surge bed forms in maar volcanoes. Amer J Sci 268:157-180.

Gernon TM, Gilbertson MA, Sparks RSJ, Field M (2009) The role of gas-fluidisation in the formation of massive volcaniclastic kimberlite. Lithos 112S:439-451.

Gernon TM, Upton BGJ, Hincks TK (2013) Eruptive history of an alkali basaltic diatreme from Elie Ness, Fife, Scotland. Bull Volc 75:1-20.

Houghton B, Wilson CJN (1989) A vesicularity index for pyroclastic deposits. Bull Volcanol 51:451-462.

Kienle J, Kyle PR, Self S, Motyka R, Lorenz V (1980) Ukinrek Maars, Alaska, I. Eruption sequence, petrology and tectonic setting. J Volcanol Geotherm Res 7:11-37.

Kurszlaukis S, Lorenz V (2008) Formation of "Tuffisitic Kimberlites" by phreatomagmatic processes. J Volcanol Geotherm Res 174:68-80.

Latutrie B, Ross P-S, White JDL (2017) Bedded to non-bedded transition at the Round Butte diatreme, Hopi Buttes volcanic field, Arizona. IAVCEI2017, Portland, Oregon, USA.

Laughlin AW, Aldrich MJ, Shafiqullah M, Husler J (1986) Tectonic implications of the age, composition, and orientation of lamprophyre dikes, Navajo volcanic field, Arizona. Earth Planet Sci Lett 76:361-374.

Lefebvre NS (2013) Volcanology of maar-diatreme volcanic vent complexes, Hopi Buttes Volcanic Field, Navajo Nation, USA. PhD thesis, University of Otago, $269 \mathrm{p}$.

Lefebvre NS, White JDL, Kjarsgaard BA (2013) Unbedded diatreme deposits reveal maar-diatreme-forming eruptive processes: Standing Rocks West, Hopi Buttes, Navajo Nation, USA. Bull Volcanol 75:1-17.

Lefebvre NS, White JDL, Kjarsgaard BA (2015) Arrested diatreme development: Standing rocks east, Hopi buttes, Navajo nation, USA. J. Volcanol. Geoth. 310:186-208.

Le Maitre RW, Streckeisen A, Zanettin B, Bas MJL, Bonin B, Bateman P (2002) Igneous Rocks: A Classification and Glossary of Terms: Recommendations of the International Union of Geological Sciences Subcommission on the Systematics of Igneous Rocks. Cambridge University Press, $236 \mathrm{p}$.

Lorenz V (1975) Formation of phreatomagmatic maar-diatreme volcanoes and its relevance to kimberlite diatremes. Phys Chem Earth 9:17-27.

Lorenz V (1986) On the growth of maars and diatremes and its relevance to the formation of tuff rings. Bull Volcanol 48:265-274.

Lorenz V (2003) Maar-diatreme volcanoes, their formation, and their setting in hard-rock or soft-rock environments. Geolines 15:63-74.

Lorenz V (2007) Syn- and posteruptive hazards of maar-diatreme volcanoes. J Volcanol Geotherm Res 159:285-312.
Lorenz V, Kurszlaukis S (2007) Root zone processes in the phreatomagmatic pipe emplacement model and consequences for the evolution of maar-diatreme volcanoes. J Volcanol Geotherm Res 159:4-32.

McClintock M, White JDL (2006) Large phreatomagmatic vent complex at Coombs Hills, Antartica: wet, explosive initiation of flood basalt volcanism in the Ferrar-Karoo LIP. Bull Volcanol 68:215-239.

McGetchin TR, Smith DC, Ehrenberg SN, Roden MF, Wilshire HG (1977) Navajo kimberlites and minettes field guide: Santa Fe, Second Annual Kimberlite Conference, 40 p.

Moore JG, Nakamura K, Alcaraz A (1966) The 1965 eruption of Taal Volcano. Science 151:955-960.

Nybo JP (2014) 40Ar/39Ar Geochronology of the Navajo Volcanic Field. MSc thesis, New Mexico Institute of Mining and Technology, $137 \mathrm{p}$.

Nybo JP, McIntosh WC, Semken S (2011) Ar-Ar phlogopite geochronology of the Navajo Volcanic Field and the Ship Rock diatreme of Northwest New Mexico define a 1.4 Ma pulse of potassic magmatism. Abstract V23A-2566 AGU Conference, San Francisco, CA.

Porritt LA, Cas RAF (2009) Reconstruction of a kimberlite eruption, using an integrated volcanological, geochemical and numerical approach: a case study of the Fox Kimberlite, NWT, Canada. J. Volcanol. Geotherm. Res. 179:241-264.

Porritt LA, Cas RAF, Crawford BB (2008) In-vent column collapse as an alternative model for massive volcaniclastic kimberlite emplacement: An example from the Fox kimberlite, Ekati Diamond Mine, NWT, Canada. J Volcanol Geotherm Res 174:90-102.

Reynolds DL (1954) Fluidization as a geological process, and its bearing on the problem of intrusive granites. Amer J Sci 252, 577-613.

Roden MF (1981) Origin of coexisting minette and ultramafic breccia, Navajo volcanic field. Contrib Mineral Petrol 77:195-206.

Roden MF, Smith DC, McDowell FW (1979) Age and extent of potassic volcanism on the Colorado Plateau. Earth Planet Sci Lett 43:279-284.

Ross P-S, White JDL (2006) Debris jets in continental phreatomagmatic volcanoes: a field study of their subterranean deposits in the Coombs Hills vent complex, Antarctica. J Volcanol Geotherm Res 149:62-84.

Ross P-S, White JDL (2012) Quantification of vesicle characteristics in some diatreme-filling deposits, and the explosivity levels of magma-water interactions within diatremes. J Volcanol Geotherm Res 245-246:55-67.

Ross P-S, Delpit S, Haller MJ, Németh K, Corbella H (2011) Influence of the substrate on maar-diatreme volcanoes-an example of a mixed setting from the Pali Aike volcanic field, Argentina. J Volcanol Geotherm Res 201:253-271.

Semken S (2003) Black rocks protruding up: the Navajo volcanic field. In: Lucas SG, Semken SC, Berglof WR, UlmerScholle DS (eds) Geology of the Zuni Plateau. New Mexico Geological Society, Fall Field Conference Guidebook 54, p. 133-138.

Sohn YK, Chough SK (1989) Depositional processes of the Suwolbong tuff ring, Cheju Island (Korea). Sedimentology 36:837-855.

Suhr P, Goth K, Lorenz V, Suhr S (2006) Long lasting subsidence and deformation in and above maar-diatreme volcanoes - a never ending story. Zeit Deut Ges Geowiss 157:491-511.

Valentine GA, White JDL (2012) Revised conceptual model for maar-diatremes: Subsurface processes, energetics, and eruptive products. Geology 40:1111-1114. 
Valentine GA, Graettinger AH, Sonder I (2014) Explosion depths for phreatomagmatic eruptions. Geophys Res Lett 41:30453051.

Vazquez JA, Ort MH (2006) Facies variation of eruption units produced by the passage of single pyroclastic surge currents, Hopi Buttes volcanic field, USA. J Volcanol Geotherm Res 154:222-236.

Vespermann D, Schmincke H-U (2000) Scoria cones and tuff rings. In: Encyclopedia of Volcanoes, First Edition, p. 683694.

Walters AL, Phillips JC, Brown RJ, Field M, Gernon T, Stripp G, Sparks RSJ (2006) The role of fluidization in the formation of volcaniclastic kimberlite: grain size observations and experimental investigation. J Volcanol Geotherm Res 155:119-137.

White JDL (1991) Maar-diatreme phreatomagmatism at Hopi Buttes, Navajo Nation (Arizona), USA. Bull Volcanol 53:239-258.

White JDL, Houghton BF (2006) Primary volcaniclastic rocks. Geology 34:677-680

White JDL, Ross P-S (2011) Maar-diatreme volcanoes: A review. J Volcanol Geotherm Res 201:1-29.

White JDL, Valentine GA (2016) Magmatic versus phreatomagmatic fragmentation: Absence of evidence is not evidence of absence. Geosphere 12, $11 \mathrm{p}$.

Williams H (1936) Pliocene volcanoes of the Navajo-Hopi country. Geol Soc Am Bull 47:111-171. 
Table 1. Description and interpretation of each facies of Cathedral Cliff.

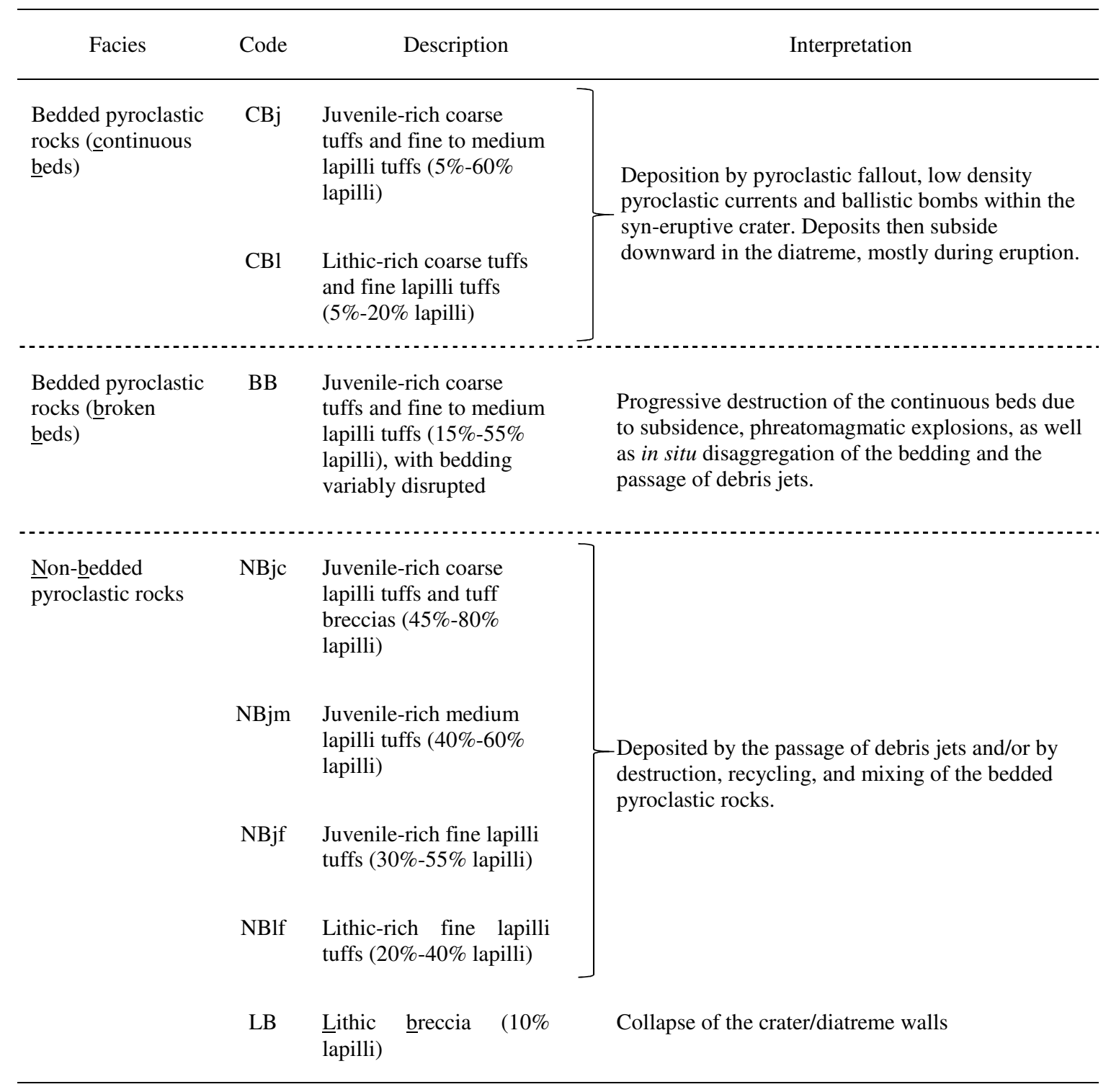


Table 2. Results (in percentage) of the petrographic point counts: $\bar{x}=$ average, Juv. frag.= juvenile fragment, Lithic frag.= lithic fragment, $\mathrm{n} / \mathrm{a}=$ not applicable.

\begin{tabular}{|c|c|c|c|c|c|c|c|c|c|c|c|c|c|c|}
\hline 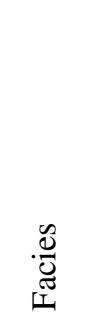 & 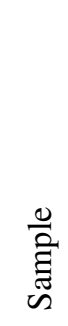 & $\begin{array}{c}\stackrel{\mathscr{Z}}{\Xi} \\
\stackrel{\Xi}{0} \\
\#\end{array}$ & $\begin{array}{l}\stackrel{000}{\Xi} \\
\stackrel{\Xi}{\Xi} \\
\ddot{\Xi}\end{array}$ & $\begin{array}{l}\stackrel{0}{\mathscr{2}} \\
\stackrel{2}{0} \\
00 \\
\frac{0}{1} \\
\frac{1}{1}\end{array}$ & 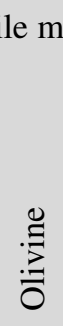 & $\begin{array}{l}\frac{0}{0} \\
\frac{\tilde{n}}{0} \\
\frac{0}{0}\end{array}$ & 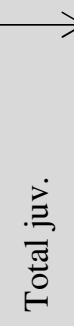 & 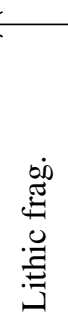 & 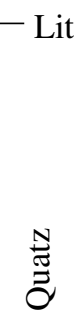 & 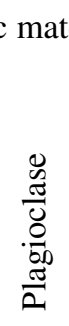 & 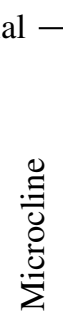 & 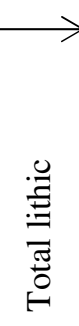 & 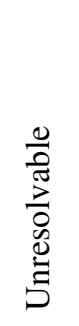 & 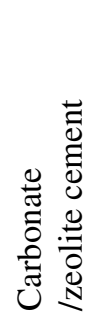 \\
\hline \multirow{6}{*}{$\mathrm{CBj}$} & $3 \mathrm{~A}$ & 390 & 59.7 & 0 & 0 & 0 & 59.7 & 4.6 & 24.1 & 0.5 & 0 & 29.2 & 9.5 & 1.5 \\
\hline & $14 \mathrm{~A}$ & 396 & 21.5 & 0.8 & 0 & 0 & 22.2 & 3.6 & 47.2 & 4.3 & 0.3 & 55.3 & 20.2 & 2.3 \\
\hline & 25 & 399 & 34.8 & 0 & 0 & 0 & 34.8 & 4.3 & 39.6 & 0 & 0 & 43.9 & 20.8 & 0.5 \\
\hline & 26 & 396 & 46.2 & 0 & 0 & 0.3 & 46.5 & 3.3 & 27.1 & 1.1 & 0 & 31.5 & 22 & 0 \\
\hline & 27 & 388 & 51.3 & 0 & 0 & 0.3 & 51.5 & 2.6 & 28.2 & 3.2 & 0 & 34.0 & 14.2 & 0.3 \\
\hline & 28 & 396 & 49.7 & 0.3 & 0 & 0.3 & 50.3 & 0.3 & 31.8 & 0 & 0 & 32.1 & 17.7 & 0 \\
\hline \multirow{2}{*}{ CB1 } & 4 & 398 & 30.9 & 0.8 & 0 & 0 & 31.7 & 2.5 & 47.7 & 1.5 & 0 & 51.8 & 16.3 & 0.3 \\
\hline & 11 & 404 & 15.8 & 0.5 & 0 & 0.5 & 16.8 & 4.2 & 57.9 & 1.7 & 0 & 63.9 & 5.9 & 13.4 \\
\hline $\bar{x} C B$ & $n / a$ & $n / a$ & 38.8 & 0.3 & 0 & 0.2 & 39.2 & 3.1 & 38 & 1.6 & 0 & 42.7 & 15.8 & 2.3 \\
\hline \multirow{4}{*}{ NBjf } & 1 & 399 & 45.4 & 1.3 & 0.3 & 0 & 46.9 & 4.5 & 24.3 & 0.3 & 0 & 29.1 & 22.3 & 1.8 \\
\hline & 7 & 398 & 41.5 & 0.3 & 0.2 & 0.1 & 42.0 & 5.0 & 33.2 & 1.8 & 0 & 39.9 & 17.8 & 0.3 \\
\hline & 9 & 395 & 38.5 & 0.3 & 0.2 & 0.3 & 39.2 & 8.9 & 37.7 & 2.0 & 0 & 48.6 & 9.9 & 2.3 \\
\hline & L15 & 403 & 33.3 & 1.0 & 0 & 0 & 34.2 & 1.7 & 47.1 & 3.0 & 0.7 & 52.6 & 12.2 & 1.0 \\
\hline \multirow{4}{*}{ NBjm } & $6 \mathrm{~A}$ & 399 & 61.4 & 0.3 & 0.1 & 0.2 & 62.0 & 6.8 & 22.8 & 1.3 & 0 & 30.8 & 6.0 & 1.3 \\
\hline & $6 \mathrm{~B}$ & 400 & 65.0 & 0 & 0.7 & 0.5 & 66.2 & 9.0 & 12.5 & 0 & 1.8 & 23.3 & 9.8 & 0.8 \\
\hline & $21 \mathrm{~A}$ & 403 & 50.4 & 0.5 & 0.2 & 0.3 & 51.4 & 6.2 & 26.1 & 0 & 0 & 32.3 & 14.4 & 2.0 \\
\hline & $22 \mathrm{~A}$ & 395 & 51.4 & 0.3 & 0 & 0 & 51.6 & 4.3 & 28.1 & 0.3 & 0 & 32.7 & 11.6 & 4.1 \\
\hline $\mathrm{NBjc}$ & 16 & 398 & 83.4 & 0 & 0 & 0 & 83.4 & 7.0 & 5.5 & 0 & 0 & 12.6 & 0 & 4.0 \\
\hline $\bar{x} N B$ & $n / a$ & $n / a$ & 52.2 & 0.4 & 0.2 & 0.2 & 53.0 & 5.9 & 26.4 & 0.9 & 0.3 & 33.5 & 11.6 & 1.9 \\
\hline $\mathrm{BB}$ & 20 & 400 & 52.5 & 0.3 & 0 & 0 & 52.8 & 9.8 & 19.8 & 2.0 & 0 & 31.5 & 11.3 & 4.5 \\
\hline
\end{tabular}




\section{Figure descriptions}

Fig. 1 Location maps. a The Navajo volcanic field $(\mathrm{N})$ sits in the center of the Colorado Plateau. Other volcanic fields are: $\mathrm{HBVF}=$ Hopi Butte volcanic field, SF $=$ San Francisco, $\mathrm{SP}=$ Springerville, $\mathrm{SR}=$ San Rafael Swell, $\mathrm{T}=$ Tuba City, $\mathrm{U}=$ Uinkaret, $\mathrm{W}=$ Wasatch Plateau. Modified from Lefebvre (2013). b Map of the Navajo volcanic field, near the intersection of Arizona (AZ), Colorado (CO), New Mexico (NM) and Utah (UT). Black circles and white triangles indicate minettes, and serpentinized ultramafic microbreccias (SUM), respectively. Monoclinal structures are: CRM = Comb Ridge Monocline, $\mathrm{EDM}=$ East Defiance Monocline and MHM = Mesaverde Hogback Monocline. Cathedral Cliff (CC), Chaistla Butte (CB) and Ship Rock (SR) are labelled. Modified from Semken (2003). c Google Earth image showing the surroundings of Cathedral Cliff (Map data: Google, Landsat/Copernicus). Minette dike and Table Mesa, an elevated sedimentary platform, are located to the $\mathrm{S}$, while the Barber Peak diatreme is located about $2 \mathrm{~km} \mathrm{SE}$.

Fig. 2 Detailed geological map of the Cathedral Cliff diatreme. For the facies codes, see Table 1. Section A-A' is the approximate position of the evolution model of Fig. 10. Inset map shows $10 \mathrm{~m}$ topographic contours and all the data gathering stations around the diatreme. The 0 m elevation is relative to that of station 1 .

Fig. 3 Geological contacts on the eastern (a) and southern (b) sub-vertical walls of Cathedral Cliff on a photographic background. For the facies codes, see Table 1. Field of view of the east wall is $\sim 150 \mathrm{~m}$ across, and $\sim 250 \mathrm{~m}$ across for the south wall.

Fig. 4 Types of contacts between lithofacies in the diatreme. a Sharp and well-defined contact between bedded and nonbedded pyroclastic rocks. b Steep to sub-vertical contacts, forming a $9 \mathrm{~m}$-wide column of non-bedded pyroclastic rocks cutting through the broken beds. c Sharp sub-vertical contact between domains of non-bedded pyroclastic rocks.

Fig. 5 Continuous beds facies. a Plane-parallel beds. b A small dune found in the lithic-rich part of the facies. c Bomb sag. d-e Aspect of the continuous beds in thin section (plane-polarized light), where juvenile fragments ' $\mathrm{J}$ ' and quartz grains 'Qtz' are identified. Pens and pencils on the photos are about $15 \mathrm{~cm}$ long.

Fig. 6 Broken beds facies. a General aspect of the broken beds with non-bedded pyroclastic rocks are identified (under the yellow dashed line). White lines are partial bedding. b Close up of Fig. 6a. $\mathbf{c}$ Progressive disaggregation of the bedding (notebook is $18 \mathrm{~cm}$-tall). d Local bomb sag. e Aspect of the broken beds in thin section (plane polarized light) where juvenile fragments 'J' and quartz grains 'Qtz' are identified.

Fig. 7 Non-bedded pyroclastic rocks. Juvenile fragments 'J' and lithic fragments 'L' are identified. a Lithic breccia composed of sandstone blocks and megablocks (white dashed lines), and domains of non-bedded lapilli tuff in between. Backpack is $0.5 \mathrm{~m}$-high. b Fine quartz-rich lapilli tuff. Pen is $15 \mathrm{~cm}$-long. c Fine juvenile-rich lapilli tuff. d Medium juvenile-rich lapilli tuff. e Coarse juvenile-rich lapilli tuff. $\mathbf{f}$ Fragments of bedded pyroclastic rocks remaining in a non-bedded domain, on the south-side of the diatreme. The fragment is almost $2 \mathrm{~m}$-long. $\mathbf{g}$ Non-bedded pyroclastic facies in thin section (plane polarized light) where juvenile fragments 'J' and quartz grains 'Qtz' are identified.

Fig. 8 Types of fragments in the Cathedral Cliff diatreme. Juvenile fragments ' $J$ ', lithic fragments 'L', feldspar 'Fsp' and phlogopite 'Phl' are identified. a Type 1 juvenile fragment in the field. b Aspect of type 1 microcrystalline juvenile fragment in thin section. c An amoeboid type 2 juvenile fragment in the field. d Type 2 juvenile fragment in thin section. e Lithic fragment. $\mathbf{f}$ Lithic fragment in thin section. The photomicrographs are all taken in plane polarized light.

Fig. 9 Line count results (pie charts). The geological explanation for the map is the same as in Fig. 2. a Matrix $(<4 \mathrm{~mm}$ fragments) versus lithic and juvenile fragments $>4 \mathrm{~mm}$. b Proportion of the different fragments $>4 \mathrm{~mm}$, without the matrix.

Fig. 10 Juvenile enrichment model. a Model showing a constant $20 \%$ addition rate of new juvenile material to the average composition and extreme values of the continuous beds. b Sketch illustrating how the average continuous beds are enriched in juvenile clasts by addition from the fragmenting dike during the first explosion cycle, with a $20 \%$ juvenile addition rate. c Model showing $10 \%$ to $40 \%$ addition rate of new juvenile material to the average composition of the continuous beds.

Fig. 11 Conceptual model for the evolution of the Cathedral Cliff diatreme, oriented SW-NE along the A-A' section (see Fig. 2). a Ascent of the minette dike towards the paleo-surface. $\mathbf{b}$ Phreatomagmatic fragmentation and formation of the proto-maar and proto-diatreme. c Collapse of a portion of the crater wall, and formation of bedded pyroclastic deposits at the bottom of the crater and in the upper diatreme. $\mathbf{d}$ Subsidence of the bedded pyroclastic deposits and formation of debris jets. e Mature diatreme. This model is not to scale. 

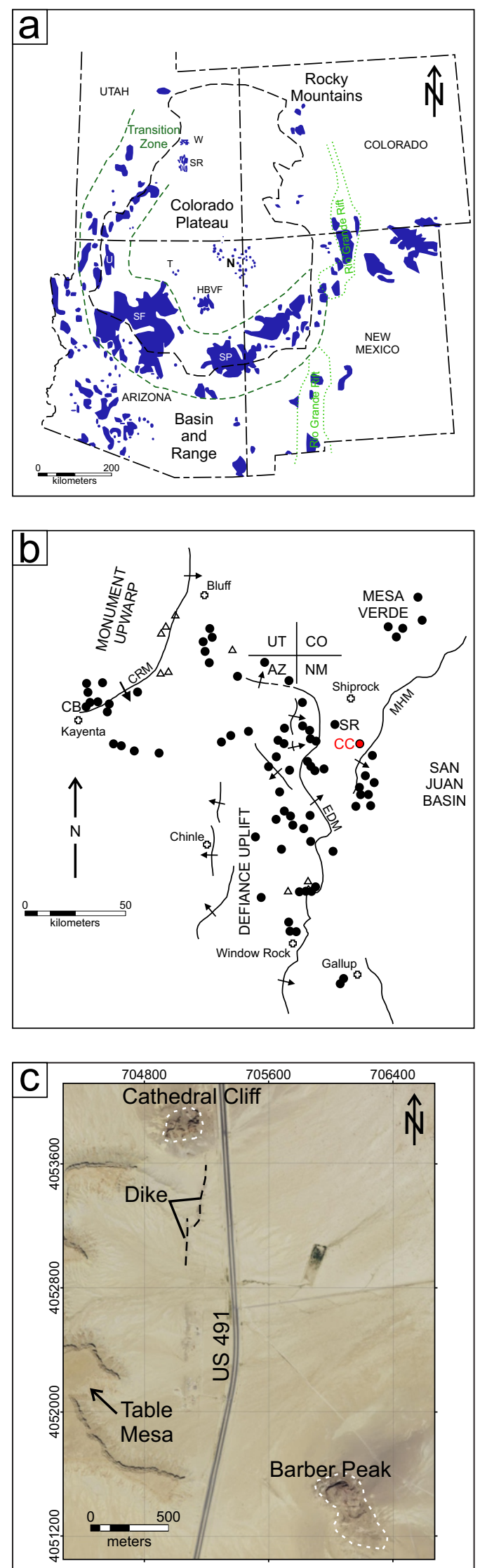

Bélanger and Ross Fig. 1 


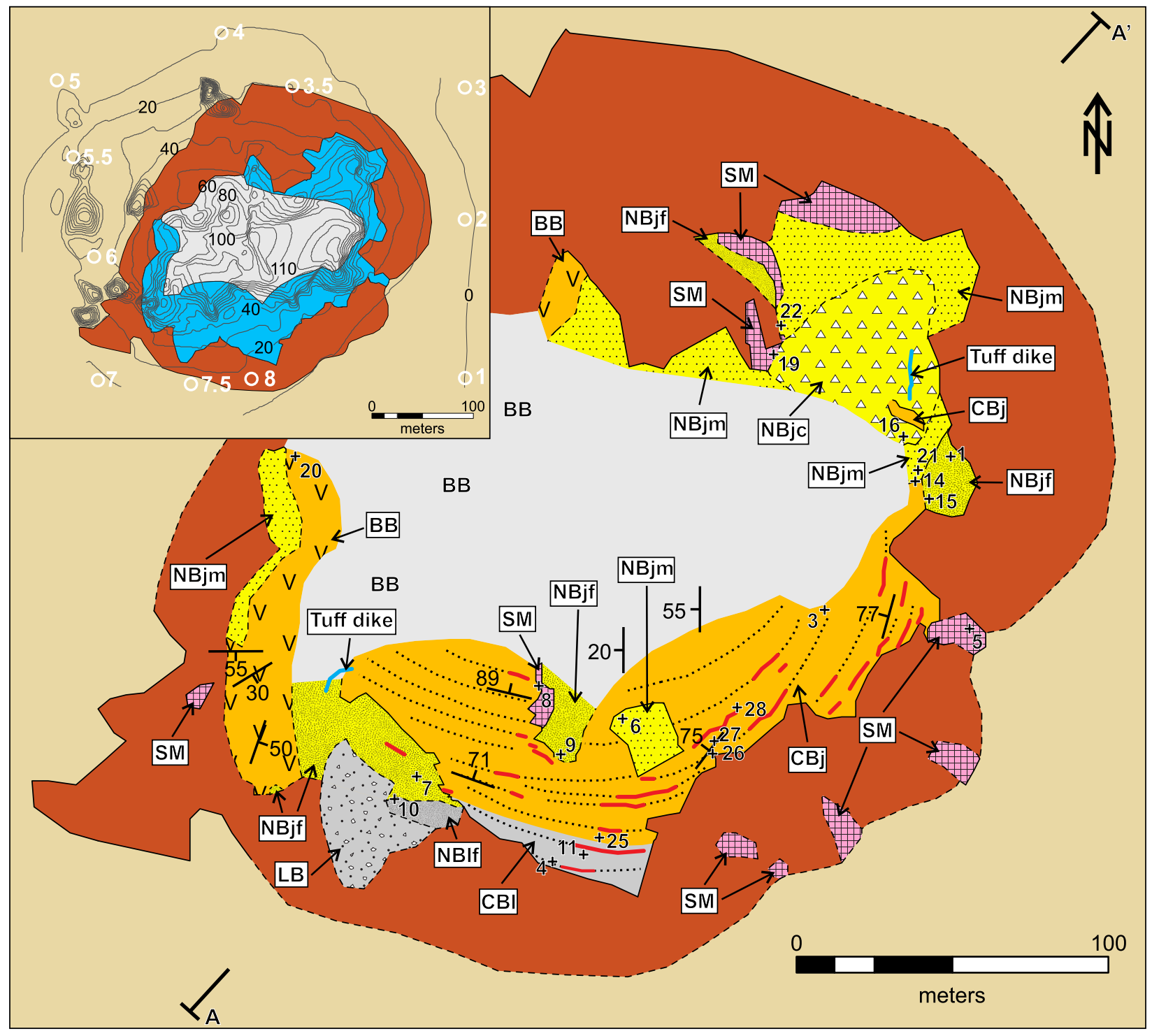

\begin{tabular}{|c|c|c|c|}
\hline Pyroclastic rocks & Other & & \\
\hline Nonbedded pyroclastic rocks & Sedimentary megablocks (SM) & 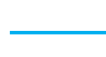 & Tuff dike \\
\hline 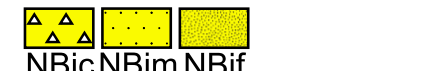 & Nondifferentiated diatreme & & Observed contact \\
\hline & Mapped area (inset map) & & \\
\hline $\begin{array}{l}\mathrm{LB} \text { NBIf } \\
\text { Bedded pyroclastic rocks }\end{array}$ & $\square$ Nonmapped area & 1 & Inferred contact \\
\hline Continuous beds & Country rock & & Dedaning \\
\hline & $\square$ Mancos shale & + & Sample \\
\hline $\begin{array}{l}\mathrm{CBj} \text { CBI } \\
\text { Broken beds } \\
v^{v} v\end{array}$ & Symbols & (a) & $\begin{array}{l}\text { Data gathering } \\
\text { stations }\end{array}$ \\
\hline $\mathrm{BB}$ & ....... Inferred continuous beds & & $\begin{array}{l}\text { Topographic } \\
\text { countours (m) }\end{array}$ \\
\hline
\end{tabular}



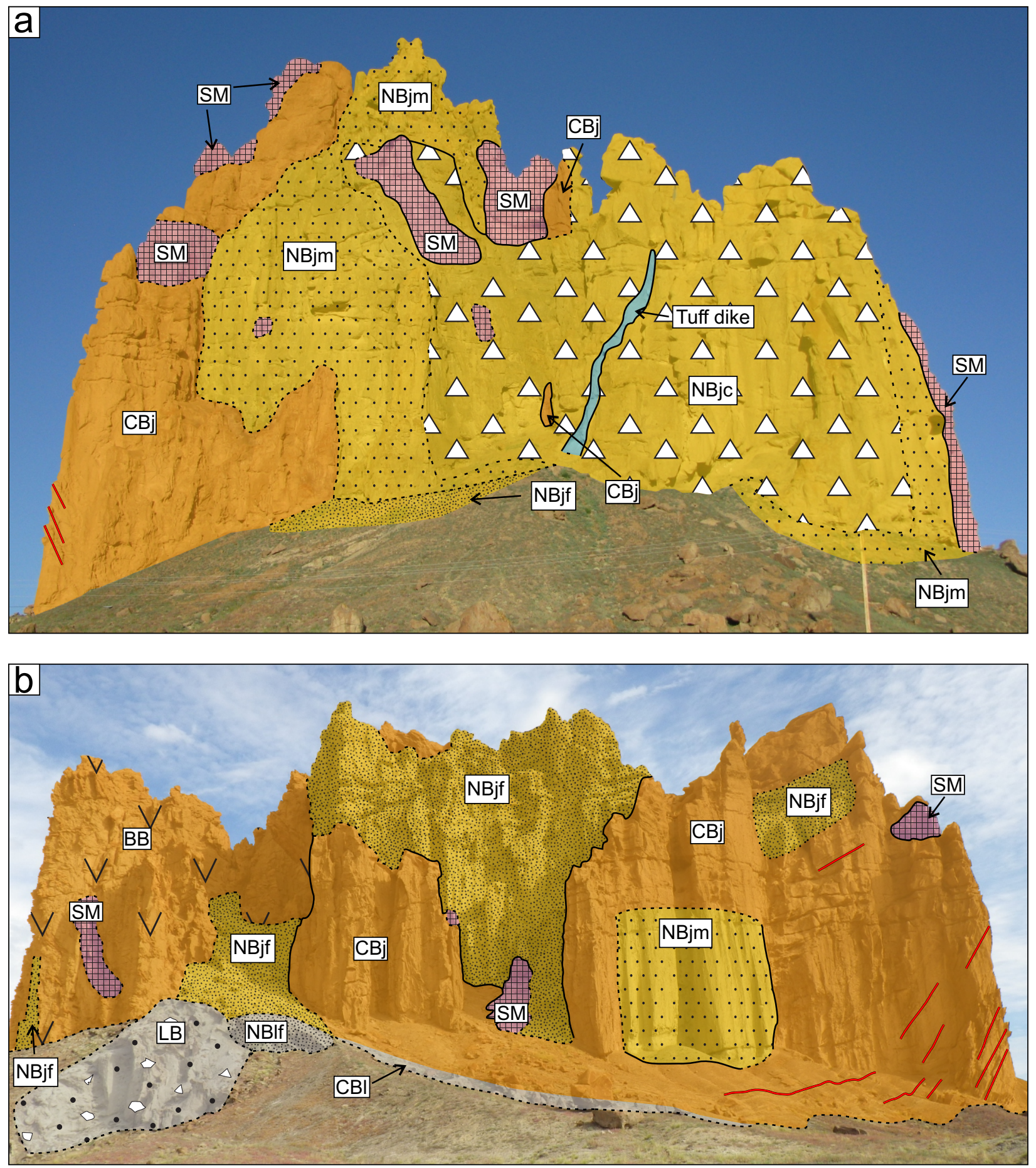

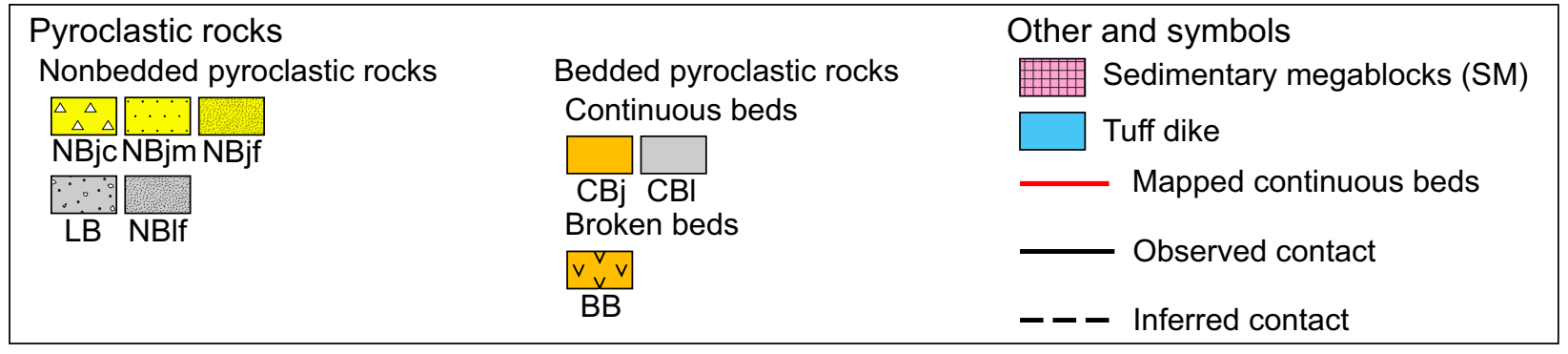

Bélanger and Ross

Fig. 3 

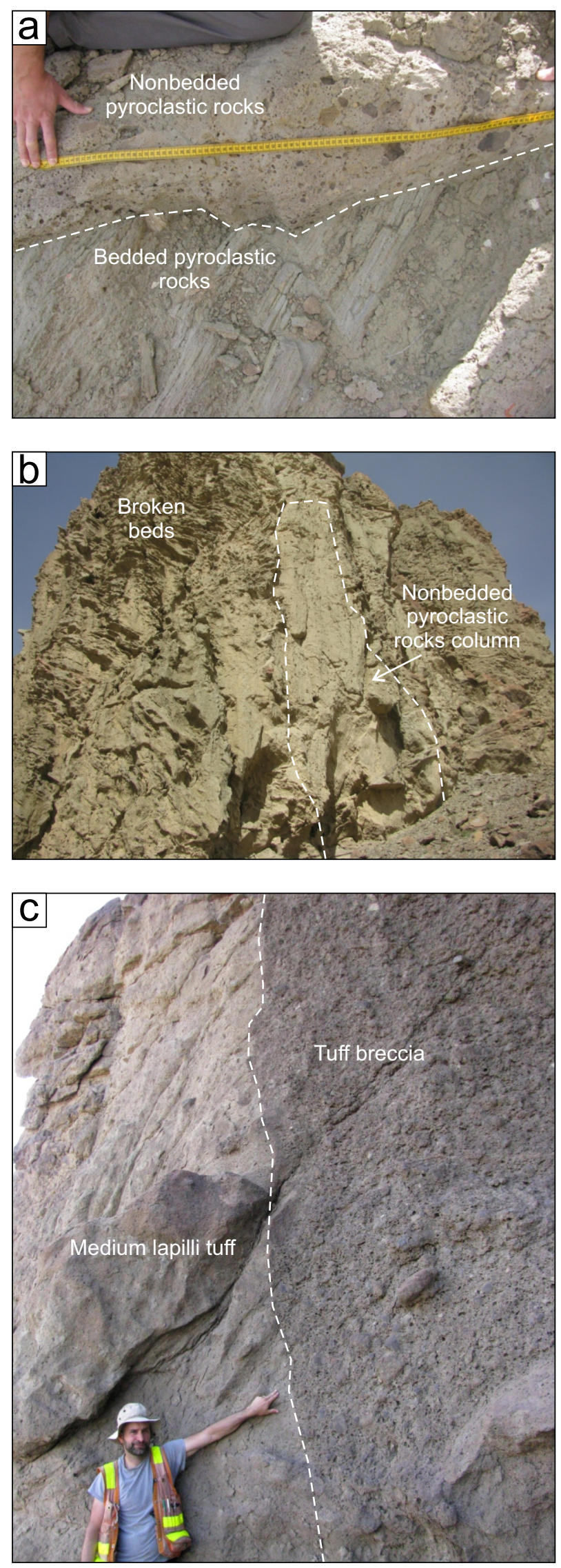

Bélanger and Ross Fig. 4 

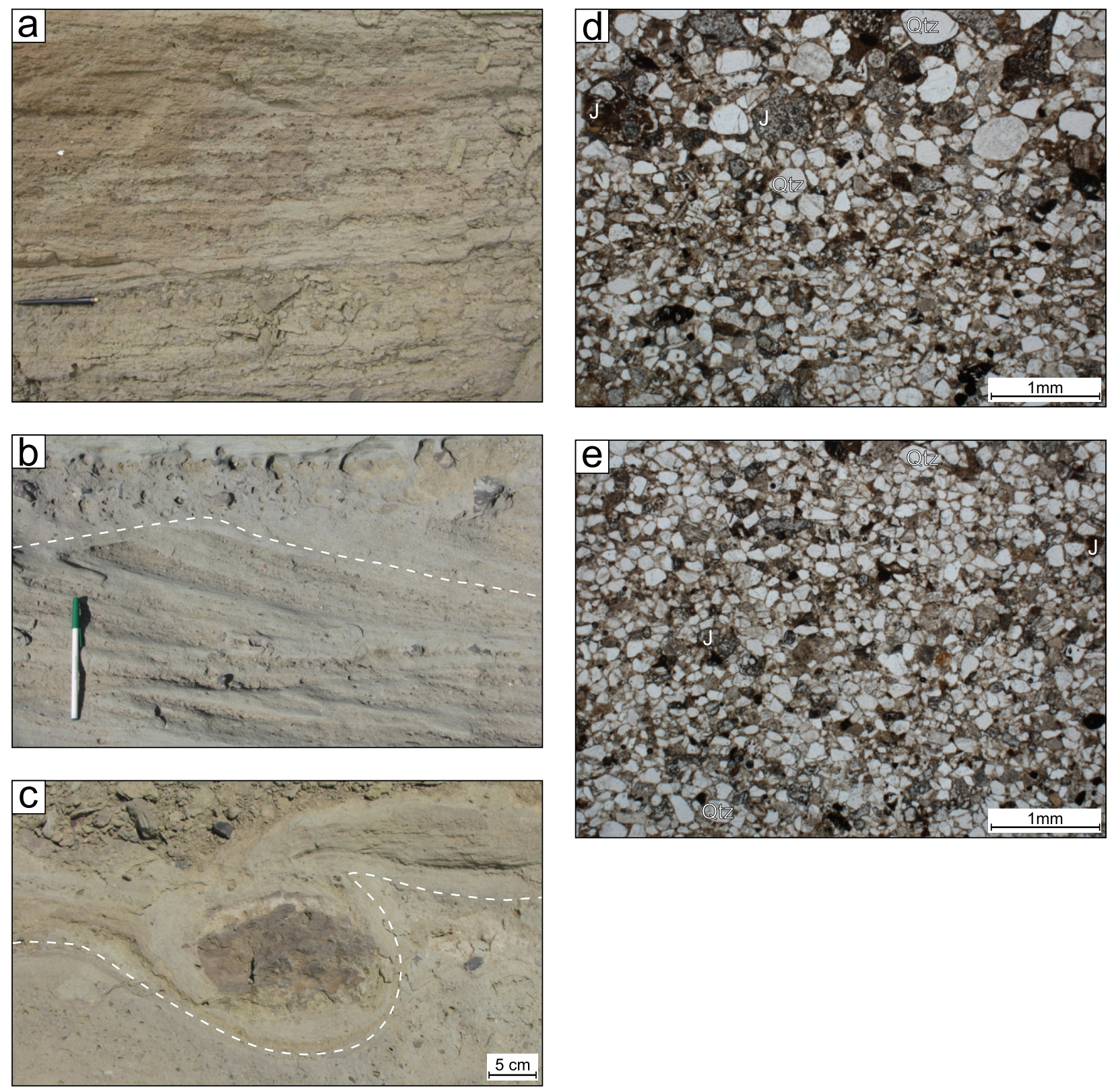

Bélanger and Ross

Fig. 5 

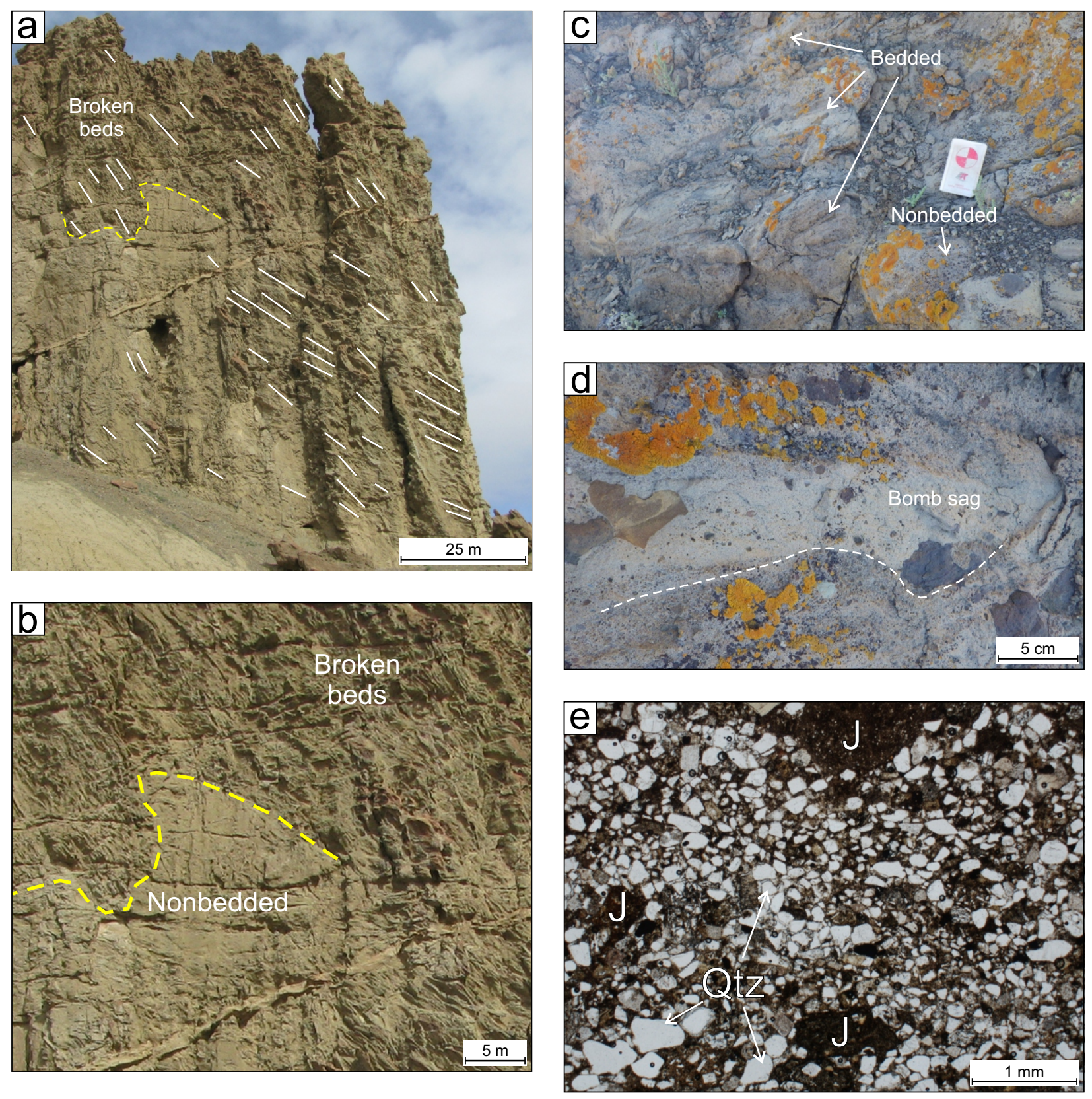

Bélanger and Ross

Fig. 6 

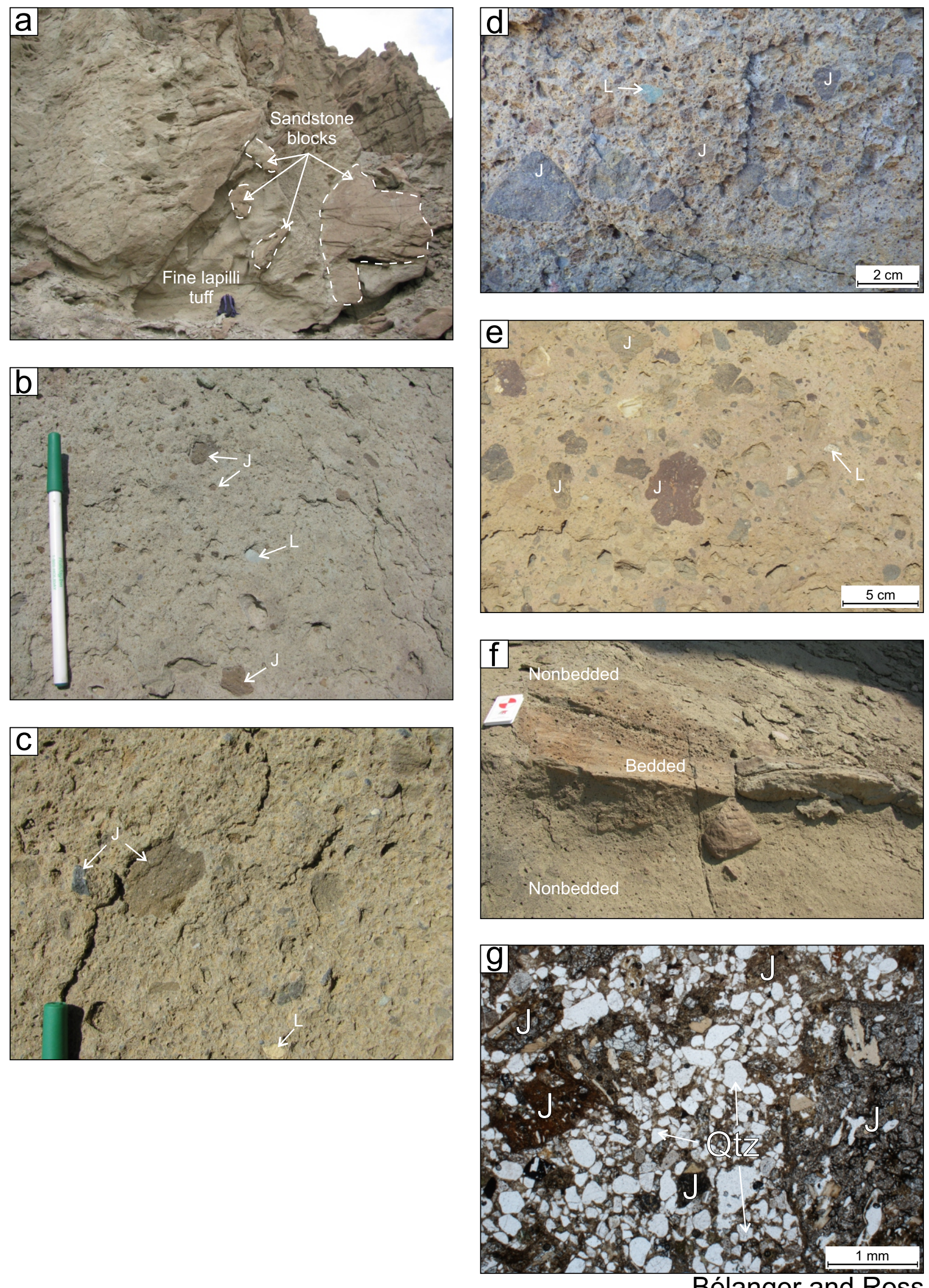

Bélanger and Ross Fig. 7 

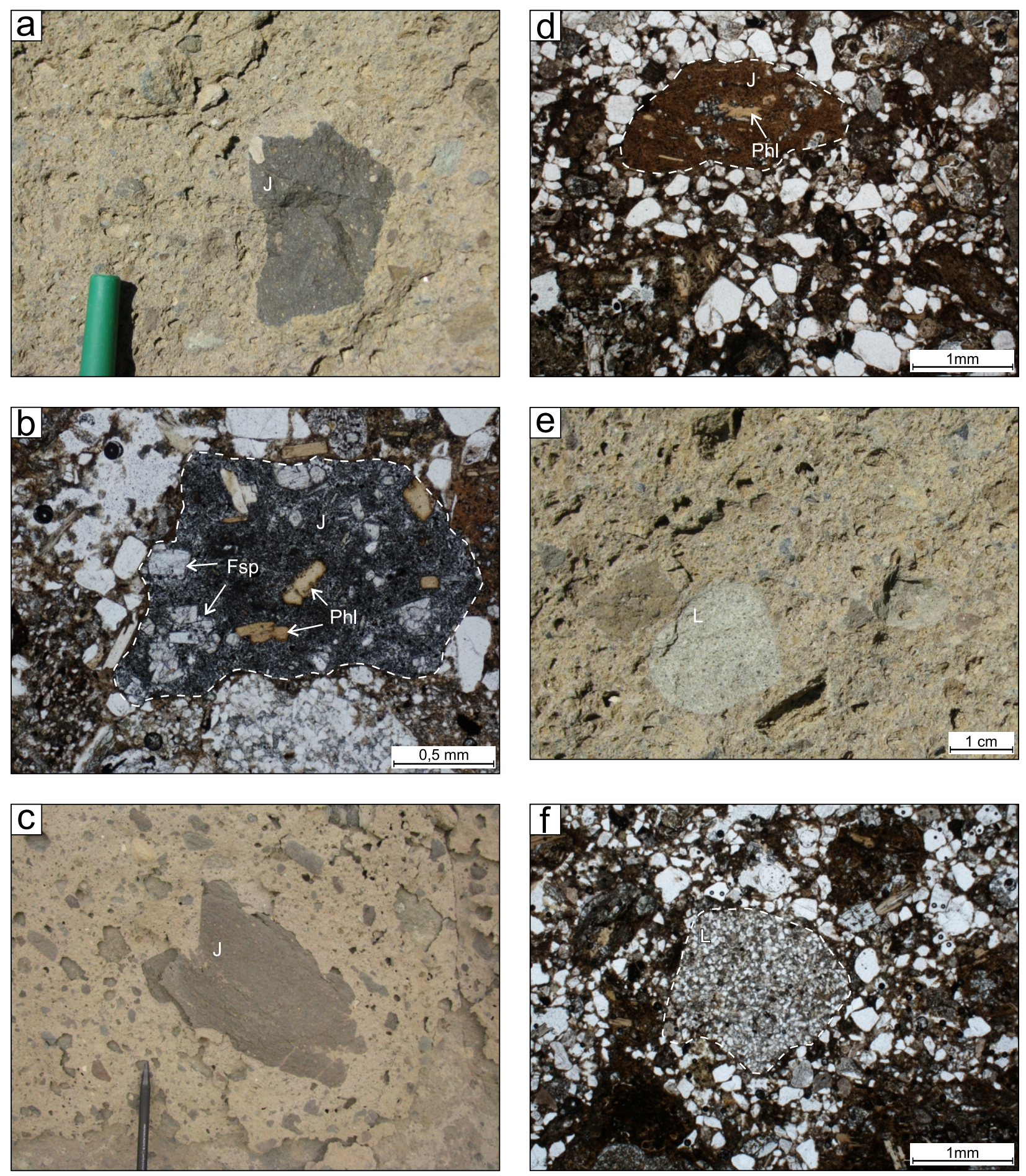

Bélanger and Ross

Fig. 8 

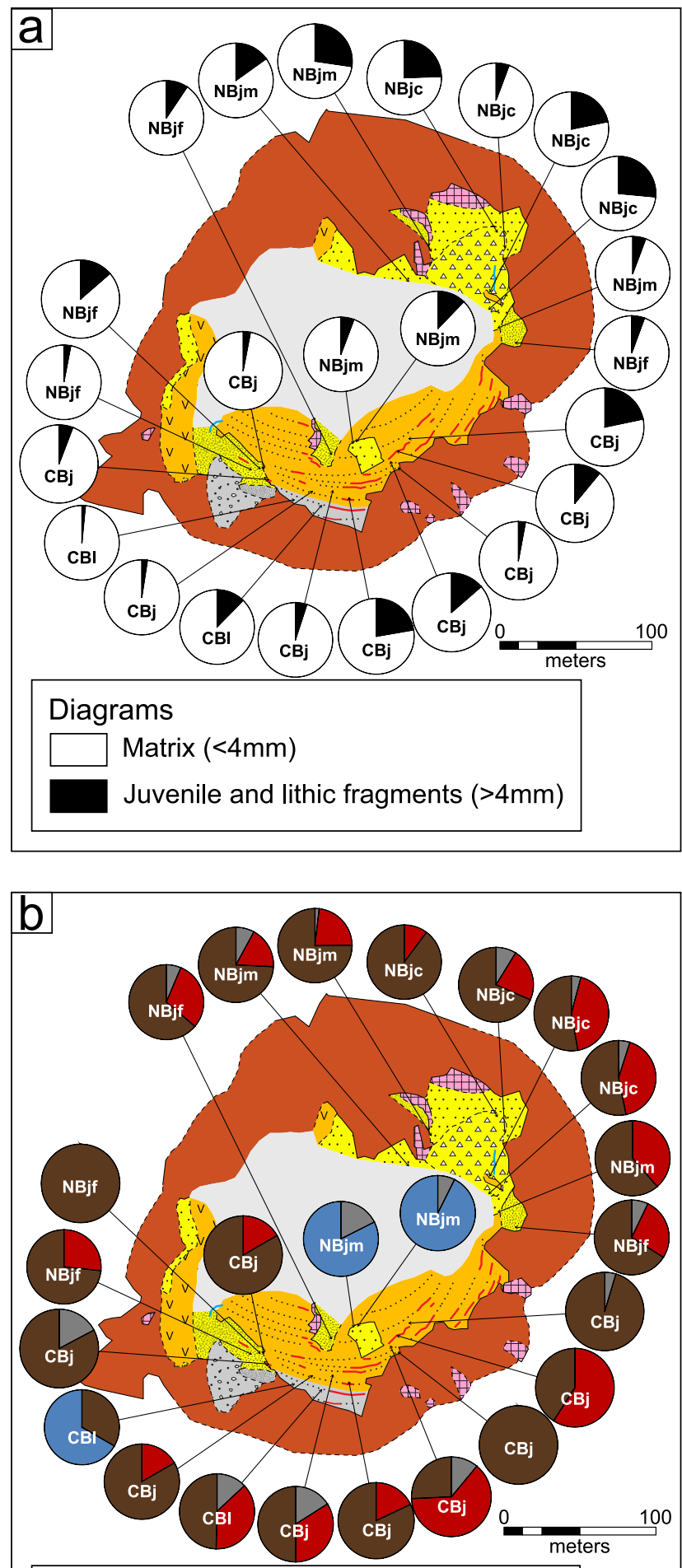

Diagrams (>4 mm fragments)

$\square$ Lithic fragments

Type 1 juvenile fragments

Type 2 juvenile fragments

Nondifferentiated juvenile fragments 

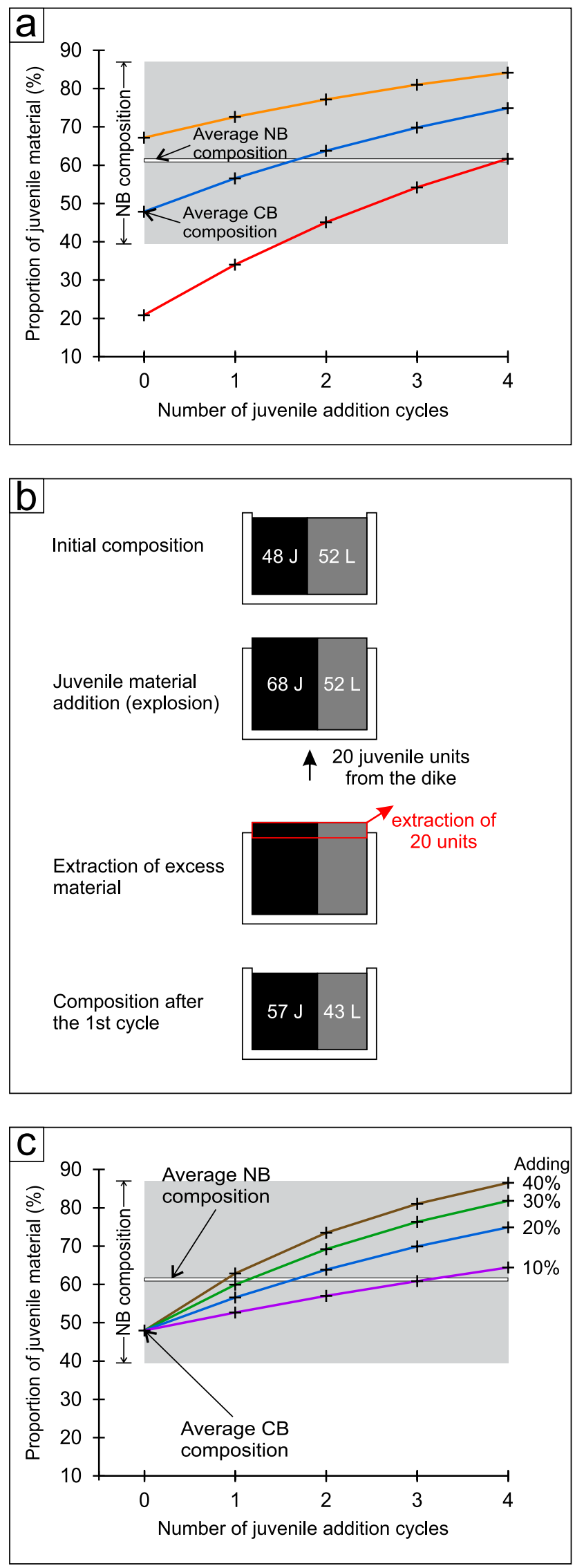

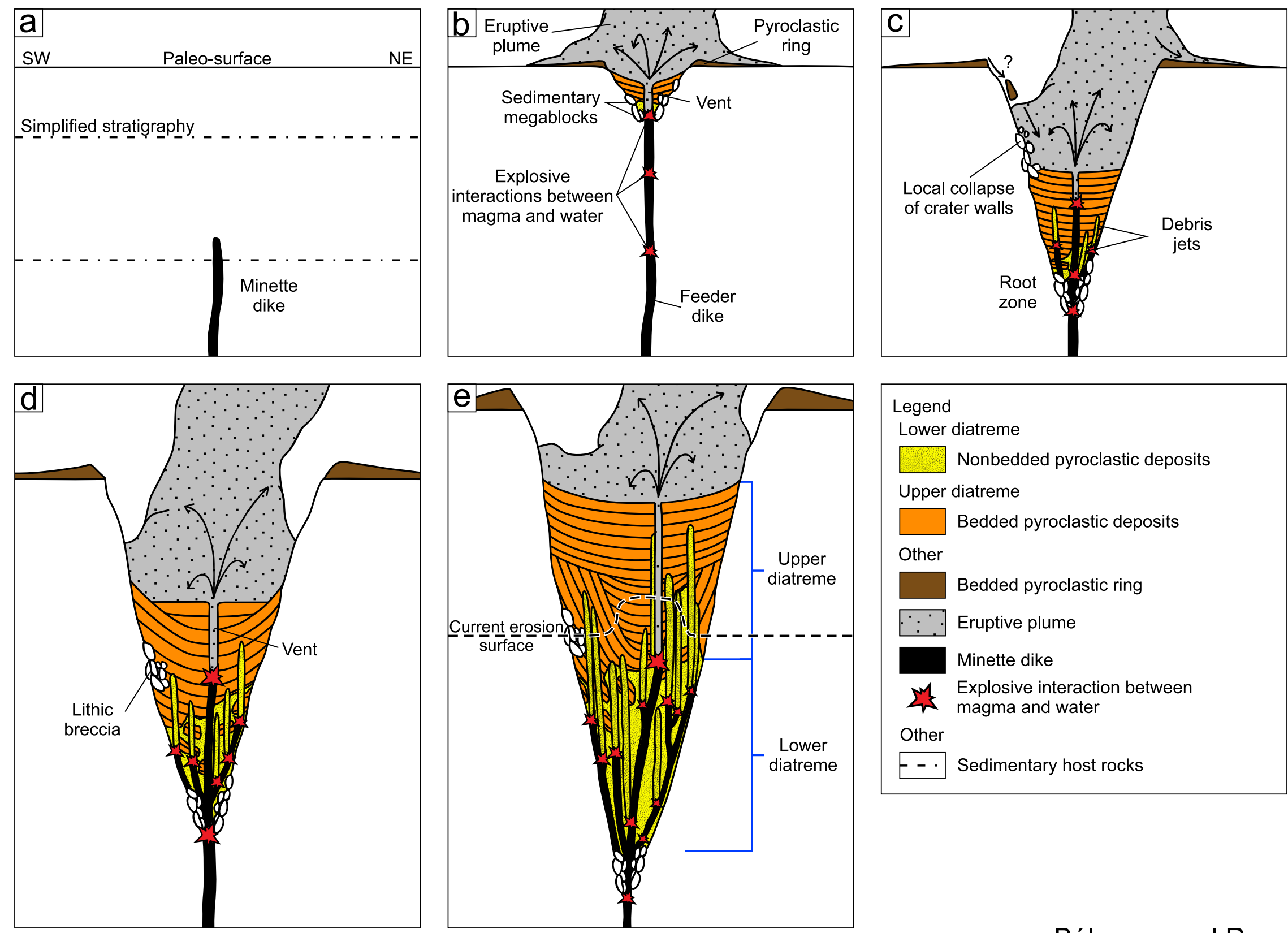

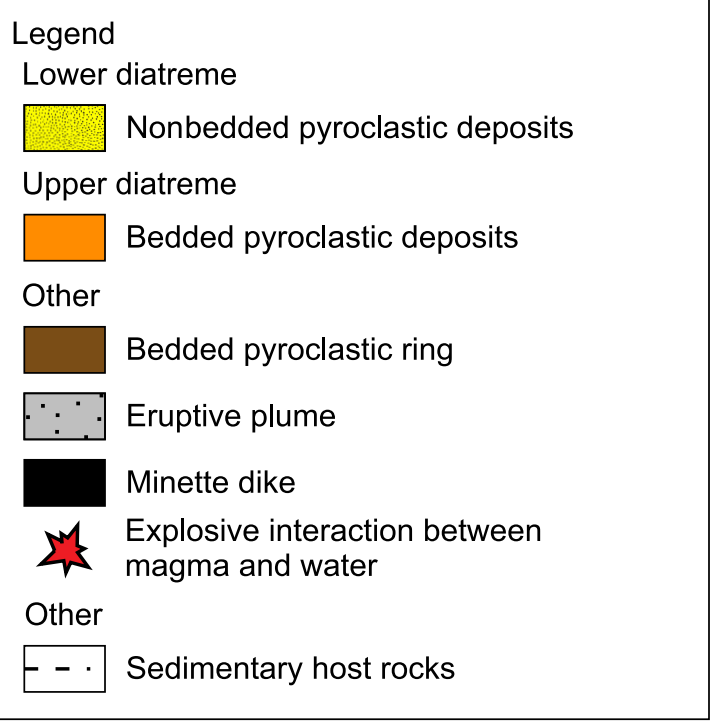

Bélanger and Ross

Fig. 11 